\title{
The sediment-fill of Pago Pago Bay (Tutuila Island, American Samoa): New insights on the sediment record of past tsunamis
}

\author{
BRIEUC RIOU*†, ERIC CHAUMILLON* , JEAN-LUC SCHNEIDER $\dagger$, \\ THIERRY CORRĖGE $\dagger$ and CATHERINE CHAGUÉ \\ *LIENSs, UMR 7266-CNRS, Université de La Rochelle, La Rochelle CEDEX, F-17000, France \\ (E-mail: brieuc.riou@u-bordeaux.fr) \\ $\dagger$ EPOC, UMR 5805-CNRS, Université de Bordeaux, Pessac CEDEX, F-33615, France \\ $\$$ School of Biological, Earth and Environment Sciences, University of New South Wales, Sydney 2052, \\ Australia
}

Associate Editor - Pedro Costa

\begin{abstract}
Extensive bathymetric and two-dimensional seismic surveys have been carried out and cores collected in Pago Pago Bay (Tutuila, American Samoa) in order to describe and gain a better understanding of the sediment fill of the bay, which was affected by the 2009 South Pacific Tsunami. Eight sedimentary units were identified over the volcanic bedrock. The basal transgressive unit displays retrograding onlaps towards the shore, whereas the overlying seven aggradational layers alternate between four draping units and three pinching out seaward units. 'Core to seismic' correlation reveals that draping units are composed of homogeneous silts, while pinching out units are dominated by very coarse coral fragments showing fresh cuts, mixed with Halimeda plates. The basal unit is attributed to transgressive sedimentation in response to flooding of the bay after the last glacial maximum, followed by the upper aggradational units corresponding to highstand sedimentation. The changeovers in these upper units indicate an alternation between low-energy silt units and high-energy coral debris units interpreted as tsunami-induced deposits. The ${ }^{14} \mathrm{C}$ dating reveals that high-energy sedimentation units can last up to approximately 2000 years while low-energy sedimentation units can last up to approximately 1000 years. This alternation, deposited during the last highstand, may be explained by cycles of tectonic activity and quiescence of the Tonga Trench subduction, which is the main source of tsunamigenic earthquakes impacting the Samoan archipelago. In the uppermost silt unit, only the geochemical signature of the terrestrial input of the 2009 SPT backwash deposits was detected between $7 \mathrm{~cm}$ and $9 \mathrm{~cm}$ depth. Hence, Pago Pago Bay offers a unique sediment record of Holocene bay-fill under the impact of past tsunamis intermittently during the last 7000 years.
\end{abstract}

Keywords Core to seismic correlation, Holocene, sediment bay-fill, shallow marine tsunami deposits, tectonic activity cycles, tsunami.

\section{INTRODUCTION}

On 29 September 2009, the Samoan Islands, including Tutuila Island (American Samoa), were struck by the 2009 South Pacific Tsunami (SPT).
This tsunami was triggered by an earthquake doublet of magnitude $8 \cdot 0$ and $8 \cdot 1$, near the northern end of the Tonga Trench (about $180 \mathrm{~km}$ south-west of Tutuila; Fig 1A and B), where the Pacific plate is subducting under the Australian 
plate (Beavan et al., 2010; Lay et al., 2010; Goff \& Dominey-Howes, 2011; Okal et al., 2011). The tsunami reached the Samoan Islands 15 to 20 min after the earthquake, causing 183 deaths in Samoa (34 of them in American Samoa) and much infrastructure damage (Dominey-Howes \& Thaman, 2009; NGDC, 2018). Between three and five waves were recorded on the Pago Pago Bay tide gauge (NOAA Service National Weather), with a maximum wave height of $8 \mathrm{~m}$ on the northern coast of Tutuila Island (Poloa Bay and Fagasa Bay) and a maximum run-up height of $20 \mathrm{~m}$ in Poloa Bay (Dominey-Howes \& Thaman, 2009; Jaffe et al., 2010; Fritz et al., 2011).

Studying tsunami deposits, like those left behind by the 2009 SPT, is crucial to understanding the impact of such devastating events, including coastal erosion, sediment movement and water flows (Jaffe \& Gelfenbaum, 2002; Jaffe \& Gelfenbuam, 2007). Knowledge gained from the study of recent deposits can also be used to identify older events in the geological record, thereby helping to reconstruct the palaeo-tsunami record over long periods of time (Pinegina \& Bourgeois, 2001; Monecke et al., 2008; Ishimura \& Miyauchi, 2015; Rubin et al., 2017). Such information could help to understand the morphological evolution of studied areas and future risk assessment (Atwater, 1987; Jaffe \& Gelfenbaum, 2002;
Nanayama et al., 2003; Williams et al., 2011). While several studies focused on inland tsunami deposits on Tutuila Island (Dominey-Howes \& Thaman, 2009; Jaffe et al., 2010; Apotsos et al., 2011; Fritz et al., 2011), none investigated shallow marine backwash deposits. In fact, few studies have been carried out on such shallow marine tsunami backwash deposits, with only a handful showing interest in recent earthquake-generated tsunamis (Abrantes et al., 2008; Donato et al., 2009; Sugawara et al., 2009; Smedile et al., 2011, 2012; Sakuna et al., 2012). If well-preserved, such deposits can provide additional information. Indeed, the shallow marine environment near the shore is not subject to subaerial erosion and might preserve both uprush and backwash tsunami deposits (Dawson \& Stewart, 2007; Nanayama, 2008). For this purpose, deep and sheltered bays with very low hydrodynamic settings could represent ideal study zones (Weiss \& Bahlburg, 2006), because they have the potential to preserve both recent tsunami deposits and palaeo-tsunami archives. Through the last decade, shallow marine tsunami and palaeo-tsunami backwash deposits have been studied in such sheltered bays, but are still under-represented in the literature (Van Den Bergh et al., 2003; Fujiwara \& Kamataki, 2007; Sugawara et al., 2009; Smedile et al., 2011, 2012).
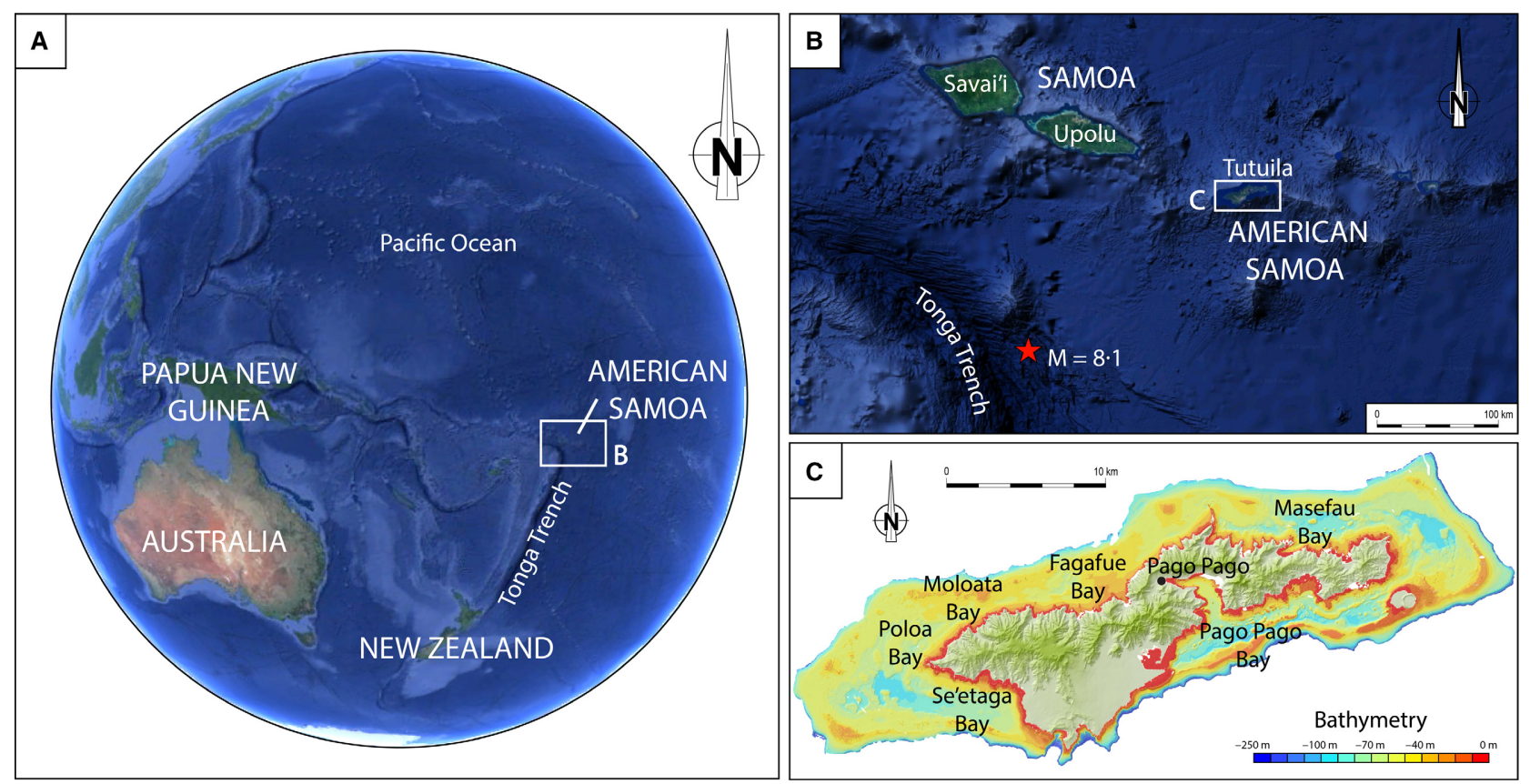

Fig. 1. (A) Location of American Samoa in the Pacific Ocean (modified from Google Earth ${ }^{\odot}$ ). (B) Location of the earthquake epicentre marked by a red star with its magnitude (modified from Google Earth ${ }^{\odot}$ ). (C) Map of Tutuila with bathymetric data (modified from NOAA, 2018; http://www.soest.hawaii.edu/pibhmc/cms/data-by-location/ american-samoa/tutuila/tutuila-bathymetry/). 
American Samoa is an ideal location for tsunami studies. Although the written historical record is not long, the tide gauge in Pago Pago Bay, Tutuila (Fig. 1), has recorded numerous tsunami events since the beginning of the 20th Century, with an average frequency of five years (Pararas-Carayannis \& Dong, 1980; Williams et al., 2011). Among these, three destructive tsunamis have been recorded; the 2009 SPT, the 1960 Great Chile earthquake tsunami and the 1917 event in similar conditions to the 2009 SPT (Pararas-Carayannis \& Dong, 1980; Okal et al., 2011). The recurrence of these events in Tutuila makes Pago Pago Bay a critical study area in reconstructing an archive of palaeo-tsunamis that impacted the island in the past. Moreover, Pago Pago Bay is a very deep and sheltered bay, with a high preservation potential of sediment record. So far, no study has focused on the geological history of Pago Pago Bay and there is no information in the literature about the sediment architecture of the bay.

The aim of this study is to show for the first time the internal architecture and sediment-fill of Pago Pago Bay. This work is based mainly on seismic and core data, combined with radiocarbon dating to understand the geological history of Pago Pago Bay. The global objective of this work is to set the geological context in order to evaluate the potential for sediment preservation and tsunami sediment record. This preliminary work is a prerequisite for further detailed investigations of the 2009 tsunami and of the palaeo-tsunami record in this part of the Pacific Ocean.

\section{STUDY AREA AND SETTING}

The Samoan archipelago is a $500 \mathrm{~km}$ long volcanic trail, associated with a hotspot, in the south-west Pacific Ocean (Fig. 1A). It is composed of three main islands. The two westernmost islands, Savai'i and Upolu, are part of Samoa, while Tutuila is part of American Samoa (Fig. 1A and B). The oldest island, Savai'i, is at the western end of the trail and is $5 \mathrm{Ma}$ (Koppers et al., 2008). This age is consistent with a Pacific plate motion of $7 \cdot 1 \mathrm{~cm}$ year $^{-1}$ towards the west in the last million years. The islands are younger and smaller eastward, and underwater volcanic seamounts are found near the present location of the hotspot. Tutuila island's shield-building volcanism started at $1.5 \mathrm{Ma}$, with Pago being the most active volcano of the five (McDougall, 1985,
2010), which formed most of the central and eastern part of the island. Savai'i, Upolu and Tutuila also show a post-erosional recent volcanic shield that is $<0.4 \mathrm{Ma}$. This recent volcanism is related to a fracture of the Pacific plate, which is due to the bending induced by the nearby subduction of the Pacific plate under the Australian plate near the Tonga Trench (Koppers et al., 2008).

Several consequences of the volcanic origin of Tutuila can be observed. First, the coastline is deeply indented by many bays all around the island, with Pago Pago Bay being the widest and deepest (Fig. 1C). These bays usually end in an amphitheatre head due to the erosion of calderas following post-volcanic subsidence (McDougall, 1985), and thus are delimited by steep slopes. Second is the presence of dense tropical vegetation combined with steep slopes. Thus the 60000 inhabitants live concentrated along the shorelines, enhancing risk in case of tsunamis (Gelfenbaum et al., 2011).

Pago Pago Bay is a long and narrow bay cutting through the southern coastline of Tutuila, with a catchment area of $c a 10 \mathrm{~km}^{2}$ (Fig. 1C). Given its origin, the morphology of the bay is very peculiar. It is composed of two segments separated by a right-angled corner. The outer segment is perpendicular to the coastline and is $3 \mathrm{~km}$ long, while the head of the bay, which extends westward after the corner, is $2 \mathrm{~km}$ long. This inner part of the bay is completely sheltered and is home to Pago Pago Harbour. This morphology, coupled with the presence of a wide fringing reef at the mouth of the bay, makes the harbour an area completely protected from all ocean waves, except for tsunami waves. This criterion is a very important one since it could lead to an ideal preservation of sediment records and particularly tsunami deposits. The depth of the bay ranges from around $60 \mathrm{~m}$ at the mouth to around $10 \mathrm{~m}$ at the head, with a gentle 1\% slope. Most of the bay stands below wind wave base.

The bottom of the bay is mostly composed of silty to clayey material. Many waste products can be found on the bottom, such as car parts or steel/ zinc house parts, attesting to recent damage around the harbour (Fig. 2A; NOAA, 2018). At the head of Pago Pago Bay, freshwater input combined with high turbidity inhibit coral growth, while in the open segment of the bay, fringing reefs are found on both sides (Mayor, 1920; Cornish \& DiDonato, 2004). These reefs are dominated by massive foliaceous coral colonies, such as Acropora (Fig. 2B), Diploastrea, Merulina, Lobophyllia, Porites and Fungia species (Green et al., 
2002). The calcifying algae Halimeda can also be found attached to the reef and on sandy beds.

Because of its location in the middle of the Pacific Ocean, the Samoan archipelago, including Tutuila, is often impacted by tsunamis originating from all around the Pacific. Unfortunately, due to a lack of written language in the Samoan culture, no data or archives are available prior to the beginning of the 19th Century. The first record of a tsunami in Tutuila dates back to 7 November, 1837 (Hitchcock, 1911; Pararas-Carayannis \& Dong, 1980), but until the beginning of the 20th Century only visual observations were archived. The Pago Pago Harbor tide gauge was set in 1948, allowing for the collection of high frequency and confident data. During the last century, more than 50 minor tsunamis have been recorded in Pago Pago Bay (Pararas-Carayannis \& Dong, 1980). However, three of these stand out in terms of power and destructive potential. The earliest and most destructive tsunami prior to the 2009 SPT was the 1917 tsunami which was generated by a magnitude 8.3 earthquake in the outer border of the northern end of the Tonga Trench, about $200 \mathrm{~km}$ off the coast of Tutuila. The first wave was recorded at around $3 \mathrm{~m}$ high and demolished many houses and two churches. No human casualties were registered. The second was the 1960 Great Chilean earthquake-associated tsunami. Waves in the head of the bay reached a maximum wave height of $5 \mathrm{~m}$, but caused minor damage to several houses and there were no casualties (Pararas-Carayannis \& Dong, 1980). Finally, the most destructive tsunami ever recorded in Tutuila was the 2009 SPT. Studies have shown that during that event, waves were amplified in the bay due to its long and narrow morphology (Fritz et al., 2011). Indeed, waves measuring around $1 \mathrm{~m}$ at the mouth of Pago Pago Bay reached a maximum wave height of $7 \mathrm{~m}$ at the head of the bay. The inundation caused considerable damage in the harbour, extending as far as $500 \mathrm{~m}$ inland, and reached a maximum run-up of $8 \mathrm{~m}$, causing 34 casualties around the island.

\section{MATERIAL AND METHODS}

\section{Dataset}

The dataset on which this work is based includes a bathymetric survey, an extensive 2D seismic survey and 16 cores (Fig. 3). All data were collected in Pago Pago Bay during the oceanographic campaign SAMOA-SPT from 27 August to 10 September 2015 aboard the $R / V$ Alis.

\section{Bathymetry}

An EM1002 multibeam sounder (Kongsberg Maritime, Kongsberg, Norway) was used for
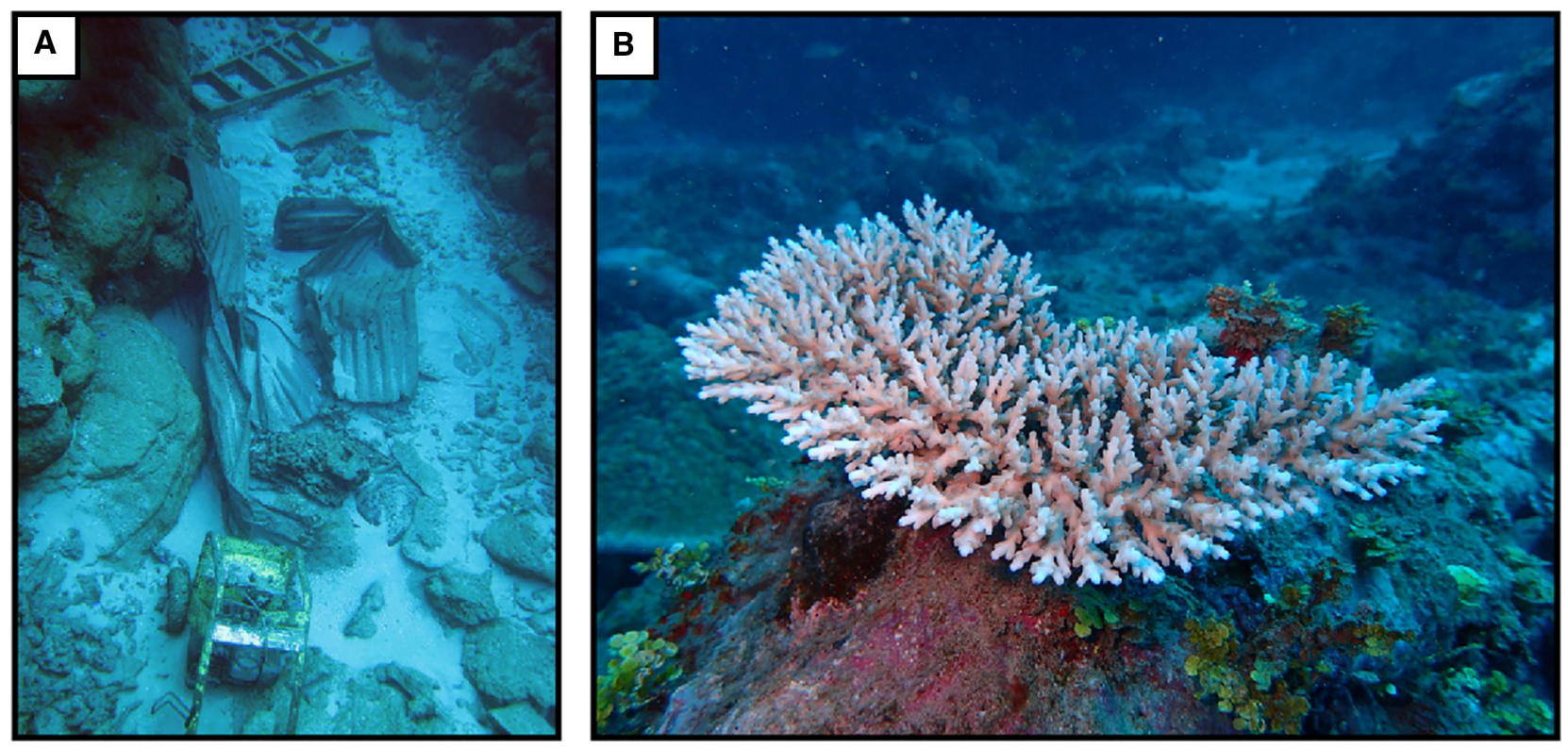

Fig. 2. (A) Photograph of the bottom of Pago Pago Bay in the inner part of the bay with a ladder, zinc house roof parts and other waste material (photograph from NOAA, 2018). (B) Photograph of Acropora found on the fringing reef of Pago Pago Bay (photograph by Stéphane Bujan). 


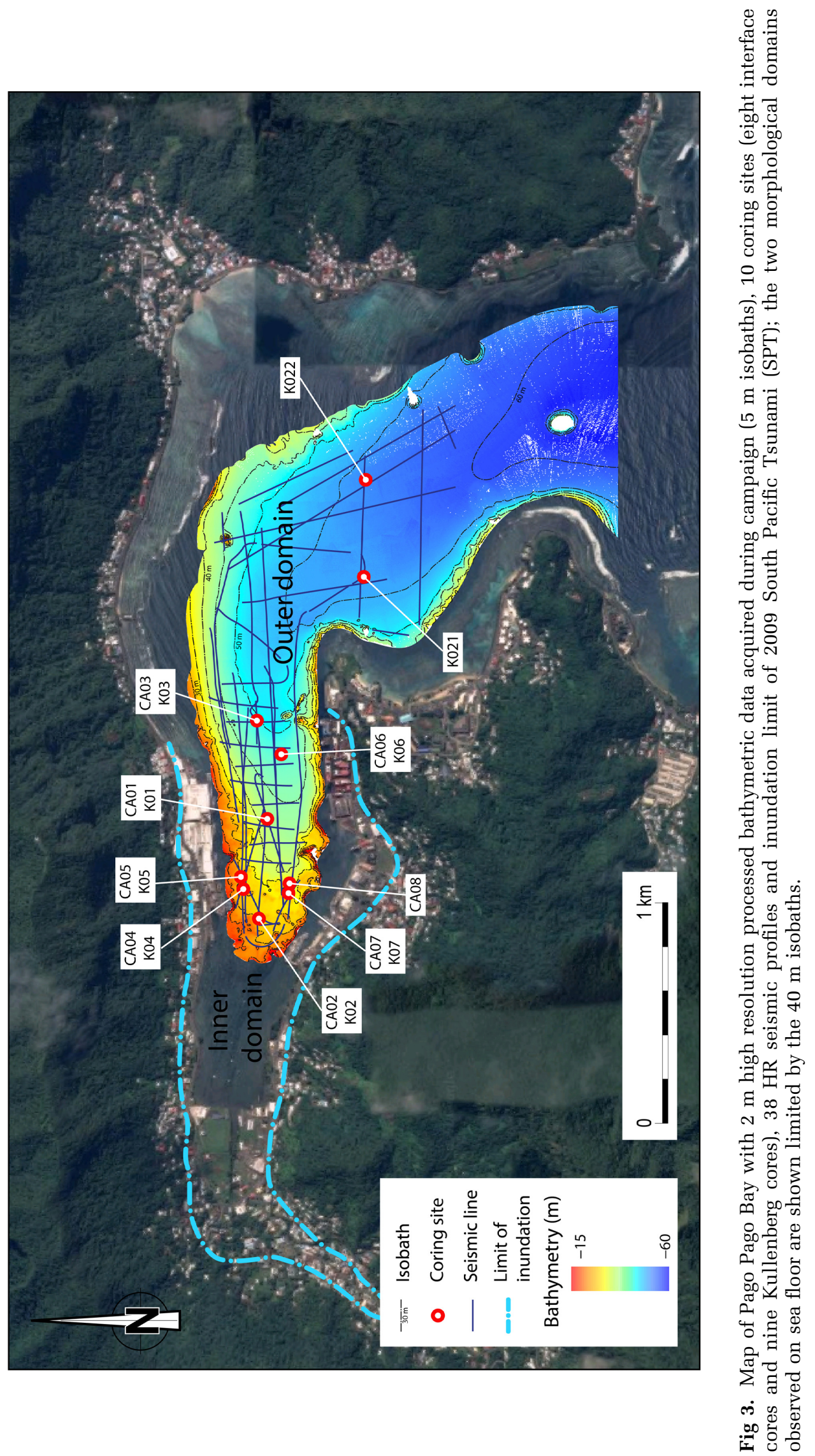


bathymetry acquisition. Its $95 \mathrm{kHz}$ frequency allowed for a depth range extending from 5 to $1000 \mathrm{~m}$, which makes it a good choice for coastal studies such as in Pago Pago Bay. Daily Sippican probe shots were made prior to the acquisition in order to calibrate the depth versus velocity model in the water column.

The raw data was then processed using the CARAÏBES (CARtography Adapted to Imagery and BathymEtry of Sonars and multibeam echosounders) software developed by CIFREMER. The first processing consisted of tide correction, before bias due to celerity variations in the water column, induced by salinity variations, was eliminated. The bathymetry was then exported as a digital elevation model (DEM) with a $2 \mathrm{~m}$ resolution elementary grid for Pago Pago Bay.

\section{Seismic}

A Seistec-IKB boomer (IKB Technologies Limited, Dartmouth, NS, Canada) was used for the seismic acquisition (Mosher \& Simpkin, 1999). Its bandwidth ranged from 1 to $10 \mathrm{kHz}$, which gave a very high resolution (around $25 \mathrm{~cm}$ of vertical resolution), allowing accurate correlations with core results (Billeaud et al., 2005; Chaumillon et al., 2008; Allard et al., 2010), with a penetration of about 20 to $100 \mathrm{~m}$ depending on the nature of the sediment (Simpkin \& Davis, 1993).

The raw profiles were processed using DELPH seismic acquisition software (CiXBlue). A frequency filter was applied between $900 \mathrm{~Hz}$ and $10500 \mathrm{~Hz}$, combined with a linear AGC (Amplitude Gain Control) for a $15 \mathrm{~ms}$ window and stacking of three adjacent traces.

\section{Cores}

Two types of coring systems were used during the campaign. Among the 16 cores, nine were collected with a Kullenberg coring device, while seven were collected with an interface coring device. The Kullenberg coring system uses a piston to dig into the sediment, and therefore can penetrate deeper (Kullenberg, 1947). During this campaign, the Kullenberg piston core lengths varied between $150 \mathrm{~cm}$ and $250 \mathrm{~cm}$. However, this system often leads to superficial soft sediment being flushed away when the device falls on the sea bottom. Therefore, interface cores were collected using a custom-made gravity box corer without piston $(1 \mathrm{~m}$ long, $10 \times 10 \mathrm{~cm}$ square section), similar in smaller dimensions to the CASQ corer (CAlypso SQuare box corer). This coring device allows sampling of the superficial soft sediment without disturbance. However, the maximum penetration with this device is only between $30 \mathrm{~cm}$ and $60 \mathrm{~cm}$.

\section{Analytical methods}

${ }^{14} \mathrm{C}$ dating

A total of 19 samples were collected for ${ }^{14} \mathrm{C}$ dating throughout five cores. Dating was undertaken at the Laboratoire de Mesure du Carbone 14 (LMC 14) in Paris (France) using the Artemis Accelerator Mass Spectrometry facility (AMS) (Beta Analytics, 2012; Miami, FL, USA). Samples were mostly coral fragments, although a few samples of Halimeda plates or gastropods were also used. The raw dates gathered were given in age BP (Before Present). Meanwhile, as measures were made on marine species, these BP ages were calibrated to take into account the reservoir age, which reflects the mixing of surface waters in equilibrium with the atmospheric ${ }^{14} \mathrm{C}$ content and older deep ocean waters upwelling in some parts of the world (Stuiver et al., 1986). For this work, the CALIB 7.1 software (Stuiver et al., 1986; http://calib.org/) was used, with the integrated Marine13 calibration curve (Reimer et al., 2013) with a global correction of 400 years (more or less) depending on the age. A local component $\Delta \mathrm{R}$ reflecting the local variations of ocean water mixing is added to this correction, with two different $\Delta \mathrm{R}$ used depending on the age of the samples. For samples younger than 2500 BP, a $\Delta \mathrm{R}$ of $20 \pm 20$ years (Petchey et al., 2008) was used based on the CALIB software Marine Reservoir Correction Database (Stuiver et al., 1986; http://calib.org/marine/). For older samples a $\Delta \mathrm{R}$ of $-101 \pm 72$ years was used (Clark et al., 2016). The calibrated ages obtained are expressed in cal yr BP. For all ${ }^{14} \mathrm{C}$ ages given in this study, the error is given as the $68.3 \%$ confidence interval (1 sigma).

\section{${ }^{210} \mathrm{~Pb}$ dating}

The ${ }^{210} \mathrm{~Pb}$ activities (half-life of $22 \cdot 3$ years) were used to indirectly date the silty material, following

Fig. 4. West-east raw (top) and interpreted (bottom) seismic profile Pago-21 with three zooms showing raw versus interpreted data in key areas to understand interpretation method; cores SPT K01, K02 and K03 were added after depth to time conversion. 

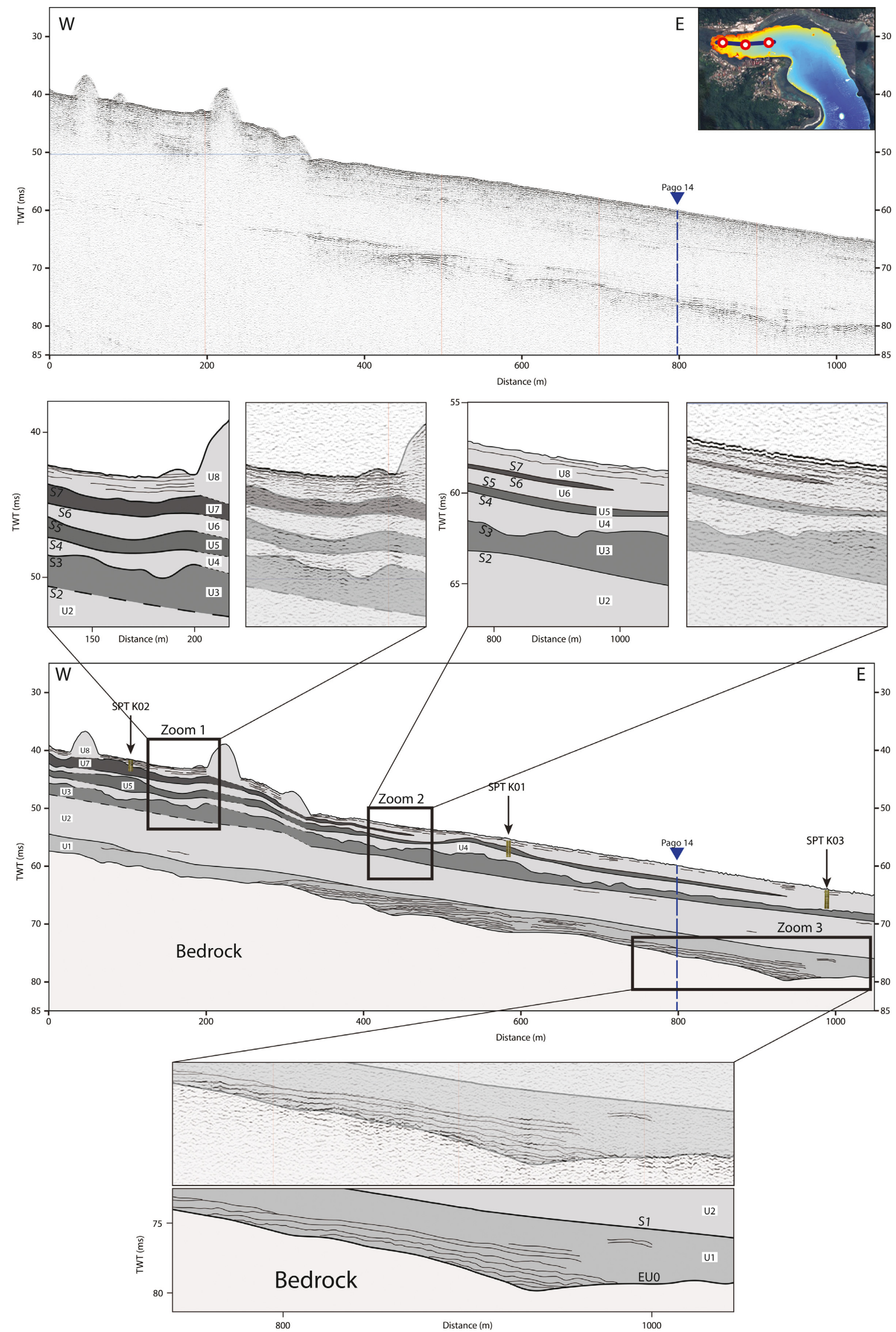

(C) 2018 The Authors. Sedimentology (C) 2018 International Association of Sedimentologists, Sedimentology, 67, 1577-1600 
a procedure similar to that of (Nittrouer et al., 1979). Samples were spiked with a known activity of ${ }^{209} \mathrm{Po}$, and were digested in concentrated $\mathrm{HNO}_{3}$ and $6 \mathrm{~N} \mathrm{HCl}$ acid: ${ }^{210} \mathrm{Po}$, the granddaughter of ${ }^{210} \mathrm{~Pb}$, and ${ }^{209} \mathrm{Po}$ was then plated onto silver planchets and $\alpha$-counted. Since secular equilibrium was not reached, the ${ }^{226} \mathrm{Ra}$-supported activity was determined from samples collected in one of the cores using $\gamma$-counting. The mean calculated ${ }^{226} \mathrm{Ra}$-supported activity of $0.84 \mathrm{dpm} \mathrm{g}^{-1}$ was then subtracted from the total activity for each measured core, leaving only the excess activity. An average accumulation rate was then calculated for each core based on the excess activity profile, so that the age of analyzed intervals could be estimated from the depth.

\section{BAY INFILLING}

\section{Sea-floor geomorphology}

Sea-floor bathymetry can provide key information that is useful in the analysis of subsurface data. When looking at the bathymetric survey of Pago Pago Bay obtained during the campaign, two main geomorphological domains stand out. The extension of these domains can be related to depth, with the limit separating the two domains corresponding to a $5 \mathrm{~m}$ high 'step' with a relatively steep slope, around 10 to $15^{\circ}$, located at the $40 \mathrm{~m}$ isobath (Fig. 3).

The first domain, called the outer domain, extends in the outer part of the bay, in areas deeper than $40 \mathrm{~m}$. Thus it covers most of Pago Pago Bay, from the mouth of the bay up to about $1 \mathrm{~km}$ from its landward end. This domain is characterized by a very flat sea floor with an absence of any geomorphological features. The slope is very steady, around $0 \cdot 5^{\circ}$.

The second domain, called the inner domain, extends into the inner part of the bay and is confined in depths shallower than $40 \mathrm{~m}$. Thus it has a limited extent, and is mostly present in the last kilometre before the landward end of the bay. Unlike the outer domain, geomorphological features including mounds and troughs cover this domain. These mounds are a few metres high $(<5 \mathrm{~m})$, by a few tens of metres wide $(<50 \mathrm{~m})$ and are round-shaped. This specific geomorphology leads to the occurrence of relatively well-connected mini-basins in the troughs in between the mounds.

\section{Subsurface seismic analysis}

\section{Characteristics of bounding surfaces}

On the seismic profiles, eight main reflectors can be identified (Figs 4 and 5); they correspond to a variation of acoustic impedance, indicative of a contrast in either lithology or grain size, but are not all associated with an unconformity. These main reflectors, or bounding surfaces, are characterized by high to moderate amplitude reflectors, with globally good continuity but locally low continuity. They separate highly contrasted seismic units, alternating high and low reflectivity, and are distinguished based on seismic and geometric characteristics. These reflectors are described below from bottom to top.

A major regional erosional unconformity EU0 is found throughout the bay. It corresponds to a very strong amplitude, low frequency and good continuity reflector displaying a highly irregular morphology. This reflector separates two main seismic units; an underlying sub-transparent acoustic basement, imputed to the eroded volcanic basement SU0; and an overlying unit showing alternations of poorly and well reflective subunits interpreted as the sedimentary bay-fill.

A major bounding surface S1 can be traced over a few kilometres at the scale of the bay and is identified as a downlap surface. It corresponds to a medium to strong amplitude, low frequency, partially continuous and sub-horizontal reflector.

Six upper bounding surfaces are not associated with unconformities identifiable from reflector geometry (i.e. toplap, downlap, onlap and erosional truncation); they show limited lateral extension $(<2 \mathrm{~km})$. From base to top: (i) S2 corresponds to a high amplitude, medium frequency and sub-horizontal reflector, highly continuous in the outer domain of the bay but discontinuous in the inner domain; (ii) S3 corresponds to a high amplitude, medium frequency, discontinuous reflector; (iii) S4 corresponds to a high amplitude, medium frequency and sub-horizontal reflector, continuous in the outer domain but discontinuous in the inner domain; (iv) S5 corresponds to a high amplitude, medium frequency and sub-horizontal reflector, continuous in the outer domain but discontinuous in the inner domain; (v) S6 corresponds to a medium amplitude, medium frequency, discontinuous and subhorizontal reflector; and (vi) S7 corresponds to a medium amplitude, medium frequency, discontinuous and sub-horizontal reflector. Three of these bounding surfaces (S3 in the inner and outer domain, S5 in the inner domain and S7 in 

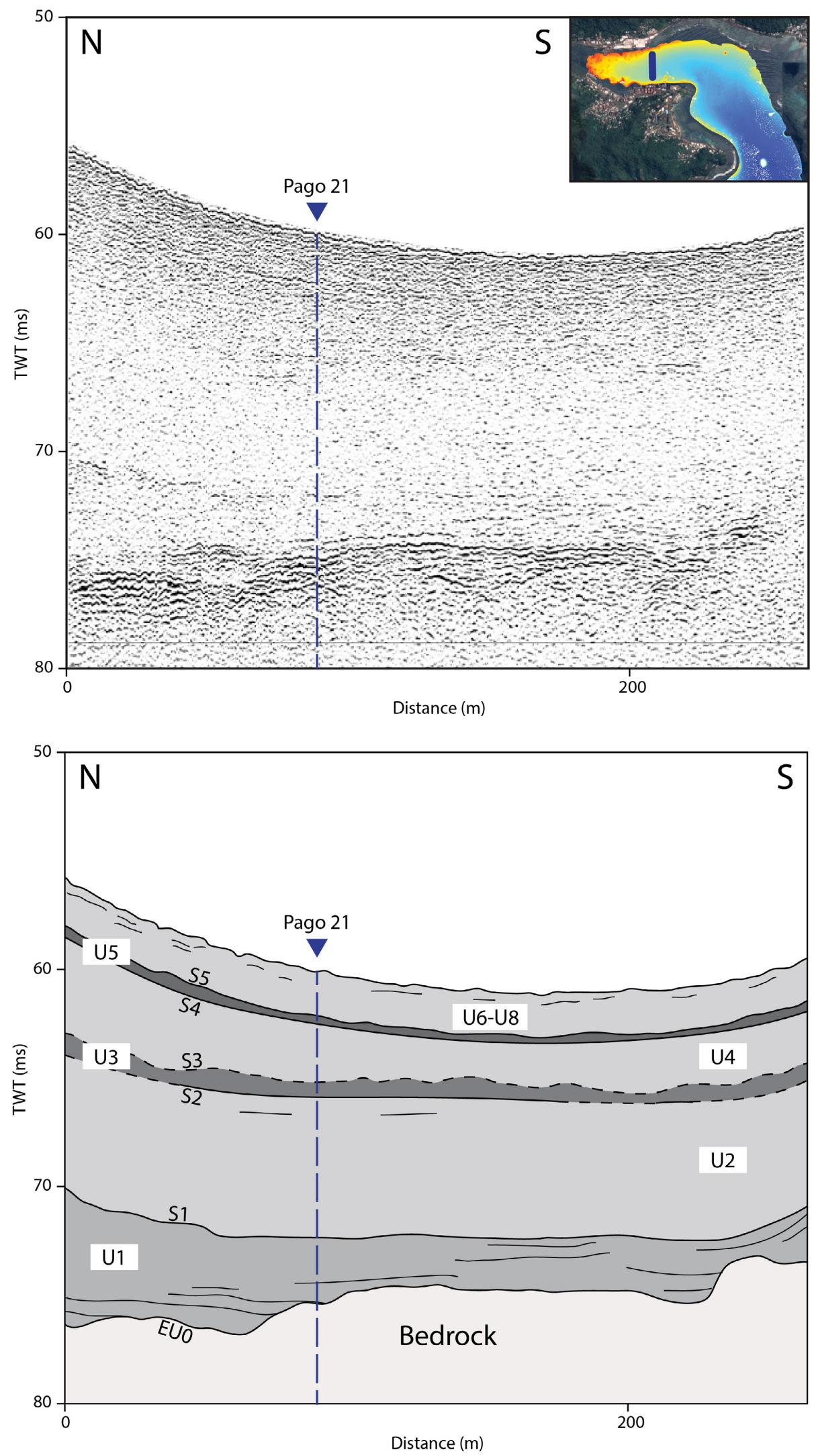

Fig. 5. North-south raw (top) and interpreted (bottom) seismic profile Pago-14. 


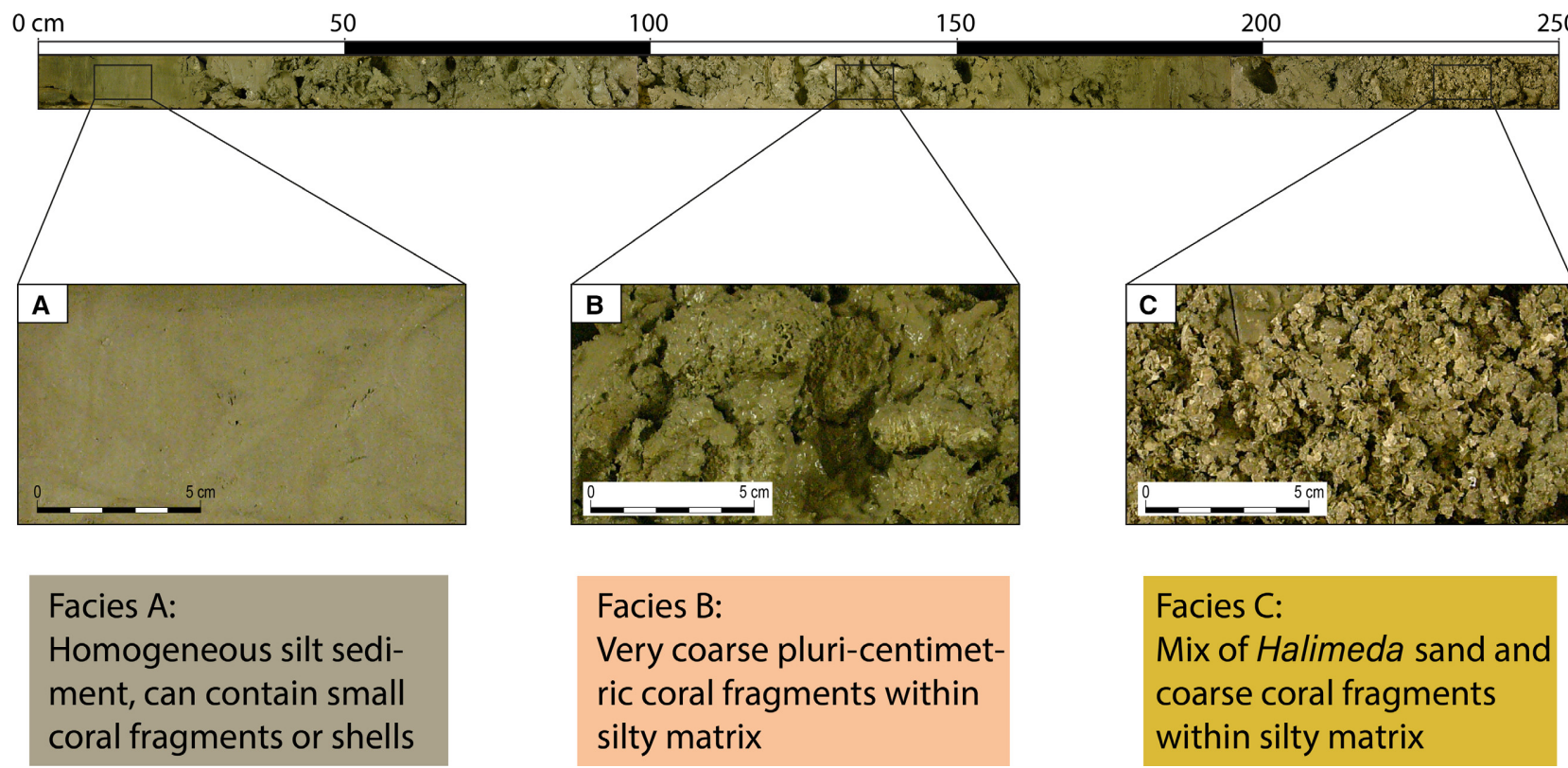

Fig. 6. Photographs of facies A (A), B (B) and C (C) taken at different depths of core SPT-K05 with description.

the inner domain) are characterized by a morphology displaying ridges and troughs.

\section{Characteristics of seismic units}

From these eight bounding surfaces, eight seismic units are defined above the acoustic basement (SU0). These units are named U1 to U8 from base to top (Figs 4 and 5) and summerized in Table 1. Altogether, they represent a total estimated thickness of approximately $12 \mathrm{~m}$ of sediment.

The basal unit U1 is a gently seaward dipping sheet drape with constant thickness. This highly reflective unit displays high amplitude, low frequency, sub-horizontal and sub-parallel continuous reflectors. The landward termination of these reflectors is onlapping over the bedrock. Locally, internal unconformities are observed with some reflectors downlapping seaward on underlying reflectors.

Unit U2 is a gently seaward dipping sheet drape with constant thickness. This poorly reflective unit displays a few medium to low amplitude, medium to low frequency, discontinuous, sub-horizontal and sub-parallel reflectors.

Units U3, U5 and U7 are seaward pinching out wedges. The lower bounding surfaces of these units are sub-horizontal (S2, S4 and S6) while their upper bounding surfaces have a ridge and trough morphology (S3, S5 and S7). Internally, they display high to medium amplitude, medium frequency, chaotic and discontinuous reflectors. Within unit U7, several additional high amplitude, irregular and continuous reflectors are observed. The acoustic facies of units U3, U5 and U7 display variations from the inner to the outer domain of the bay, with a stronger reflectivity in the inner domain and a noisy and medium reflectivity in the outer domain.

Units U4 and U6 are gently seaward dipping sheet drape units with relatively even thickness throughout the bay. These units are sub-transparent.

The uppermost unit, U8, is a gently seaward dipping sheet drape unit with even thickness throughout the bay. This highly reflective unit displays high amplitude, medium frequency, subhorizontal and sub-parallel continuous minor reflectors, notably near the top. This increase of the amplitude of the reflectors towards the top is probably due to the attenuation of the signal as it passed the first metre or so. In the troughs, between the mounds in the inner domain of the bay, some of these minor reflectors show onlapping terminations on the underlying unit. Seaward, past the pinch outs described for units U3, U5 and U7, units U2, U4, U6 and U8 merge as a unique sub-transparent, low reflectivity seismic unit without distinguishable reflectors.

\section{Core description}

\section{Facies description and distribution}

Based on macroscopic observations, grain size and shell content, three main sediment facies 


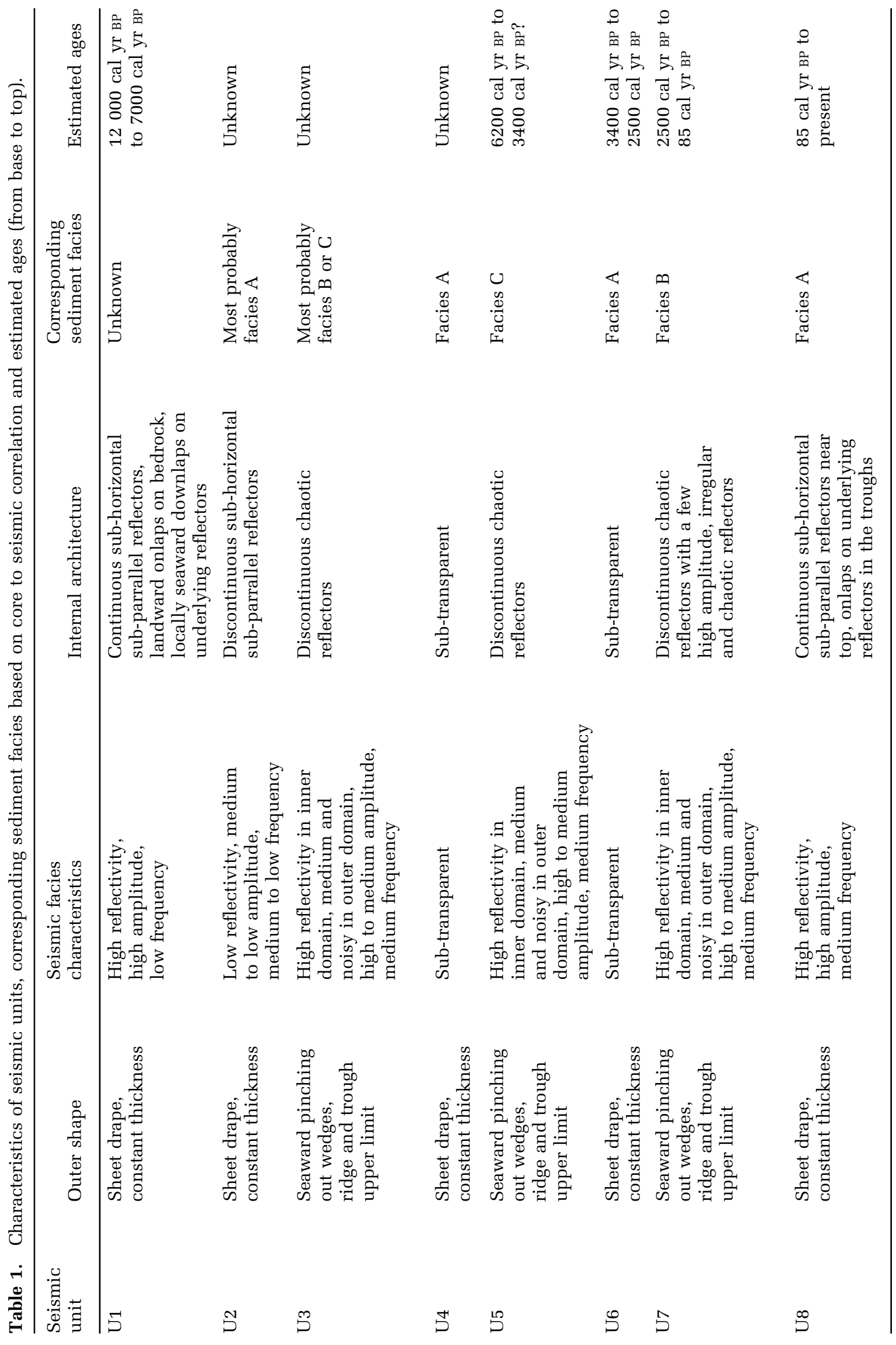


Table 2. Facies distribution with depth of occurrence in each core from proximal (top) to distal (bottom).

\begin{tabular}{|c|c|c|c|}
\hline Core & Facies A & Facies B & Facies C \\
\hline CA04 & 0 to $58 \mathrm{~cm}$ & / & / \\
\hline K04 & 130 to $167 \mathrm{~cm}$ & 0 to $130 \mathrm{~cm}$ & 167 to $251 \mathrm{~cm}$ \\
\hline CA05 & 0 to $48 \mathrm{~cm}$ & / & / \\
\hline K05 & $\begin{array}{l}0 \text { to } 25 \mathrm{~cm} \\
179 \text { to } 203 \mathrm{~cm}\end{array}$ & 25 to $179 \mathrm{~cm}$ & 203 to $253 \mathrm{~cm}$ \\
\hline CA02 & 0 to $28 \mathrm{~cm}$ & / & / \\
\hline K02 & 0 to $90 \mathrm{~cm}$ & 123 to $176 \mathrm{~cm}$ & 90 to $123 \mathrm{~cm}$ \\
\hline CA07 & 0 to $54 \mathrm{~cm}$ & / & I \\
\hline K07 & 0 to $12 \mathrm{~cm}$ & 12 to $178 \mathrm{~cm}$ & / \\
\hline CA01 & 0 to $29 \mathrm{~cm}$ & I & / \\
\hline K01 & $\begin{array}{l}0 \text { to } 90 \mathrm{~cm} \\
175 \text { to } 234 \mathrm{~cm}\end{array}$ & / & 90 to $175 \mathrm{~cm}$ \\
\hline CA03 & 0 to $49 \mathrm{~cm}$ & I & / \\
\hline K03 & 0 to $262 \mathrm{~cm}$ & / & / \\
\hline K06 & 0 to $260 \mathrm{~cm}$ & / & / \\
\hline K21 & 0 to $157 \mathrm{~cm}$ & / & / \\
\hline K22 & 0 to $170 \mathrm{~cm}$ & / & / \\
\hline
\end{tabular}

labelled A, B and C (Fig. 6) were identified and indexed in Table 2. Facies $\mathrm{A}$ is composed of very homogeneous brown silt. No apparent layering can be recognized, but elongated darker patches are seen in some cores. Some rare small coral fragments or rhodophyte concretions along with small intact shells, mainly gastropods, are found scattered in the cores.

Facies B is a non-consolidated bioclastic clastsupported breccia composed mainly of coarse coral fragments. These coral fragments are all roughly the same size, measuring from 5 to $10 \mathrm{~cm}$, with very fresh cuts. The corals are mainly Porites cylindrica, Fungia fungites, Mycedium elephantotus and Pocillopora damicornis (Fig. 7). Some Halimeda plates and broken gastropods can also be found mixed with the coral fragments, but in smaller amounts. The matrix is composed of brown silt, similar to that of facies A.

Facies $\mathrm{C}$ is a bioclastic sand mainly composed of Halimeda plates, mixed with an important fraction of coarse coral debris, similar to those found in facies $\mathrm{B}$, and measuring about $5 \mathrm{~cm}$. A few broken gastropods also occur in this assemblage. This facies is fining-upward. The matrix around the Halimeda plates and coral fragments is composed of brown silt, similar to that of facies $\mathrm{A}$.

Different successions in the vertical distribution of these three facies are observed along a transect from the inner to the outer domain of
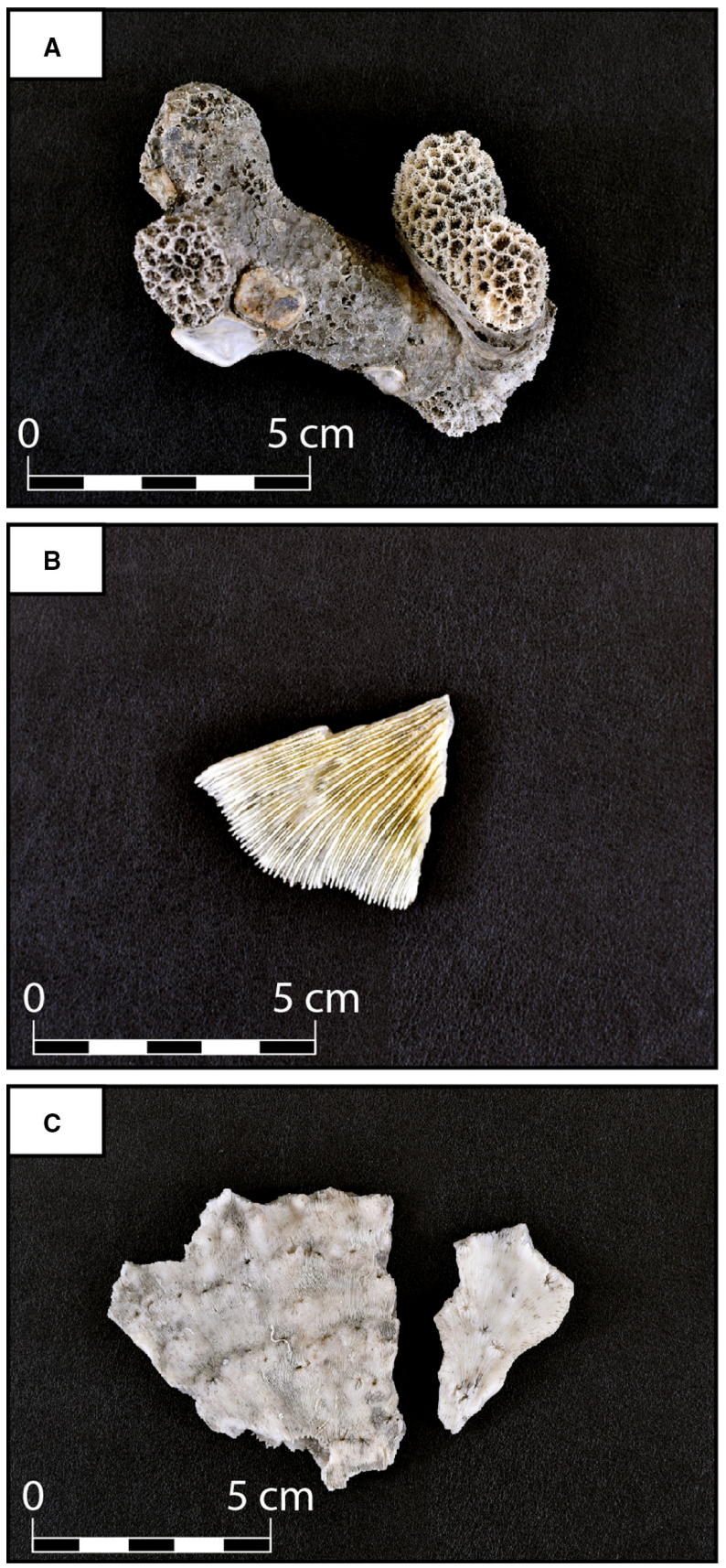

Fig. 7. Photographs of samples of the main fragmented coral species found in the cores from facies $B$ and C. (A) Porites cyclindrica (SPT-K05; $203 \mathrm{~cm}$ ). (B) Fungia fungites (SPT-K04; $67 \mathrm{~cm}$ ). (C) Mycedium elephantotus (SPT-K04; $30 \mathrm{~cm}$ ).

the bay (Fig. 8). These successions are described in the following from bottom to top.

In the inner part of the bay, the sampled sedimentary succession consists of an interval of facies $\mathrm{C}$ at the base, followed by a thin interval of facies $\mathrm{A}$, an interval of facies $\mathrm{B}$ and a final 

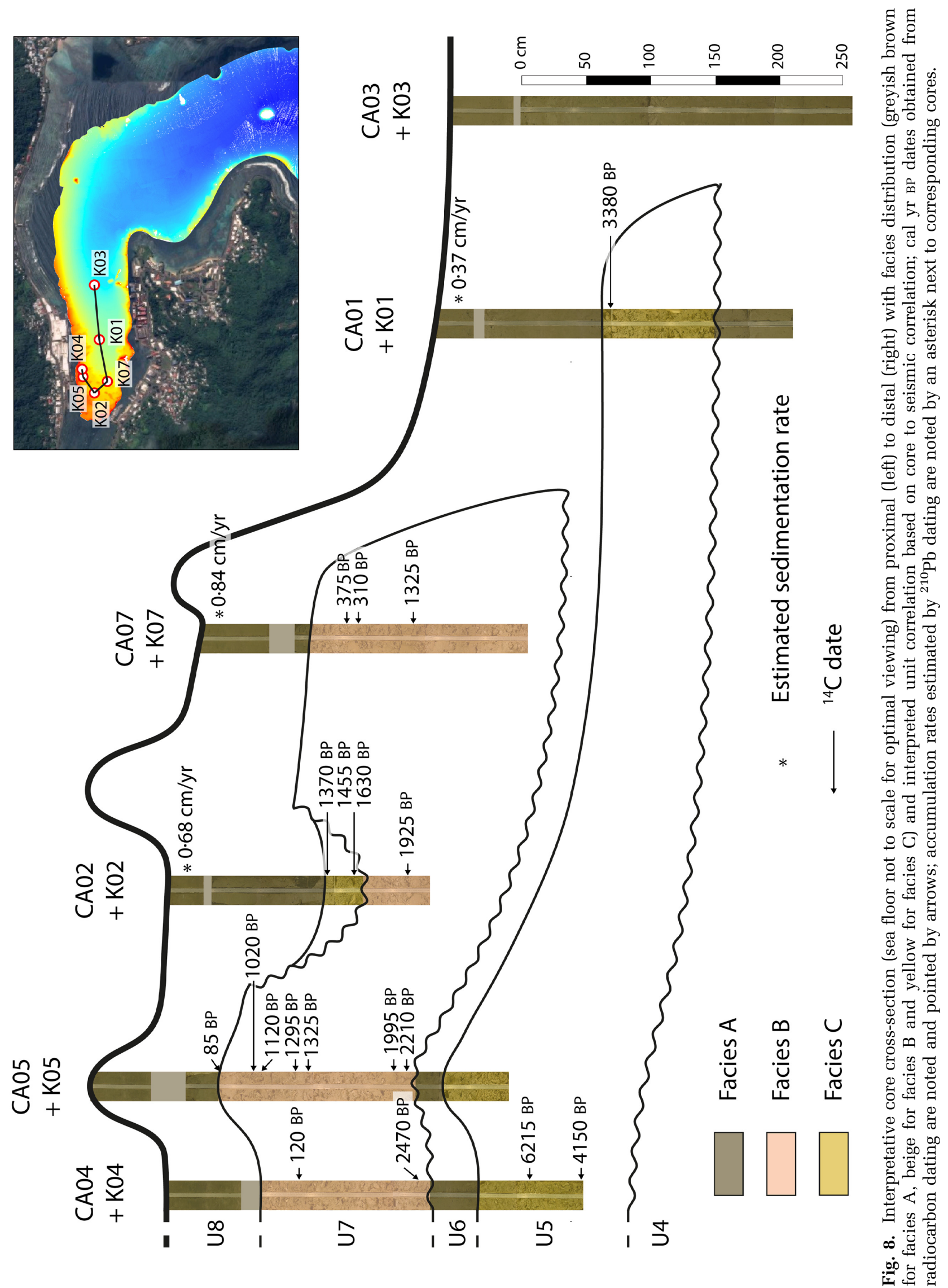


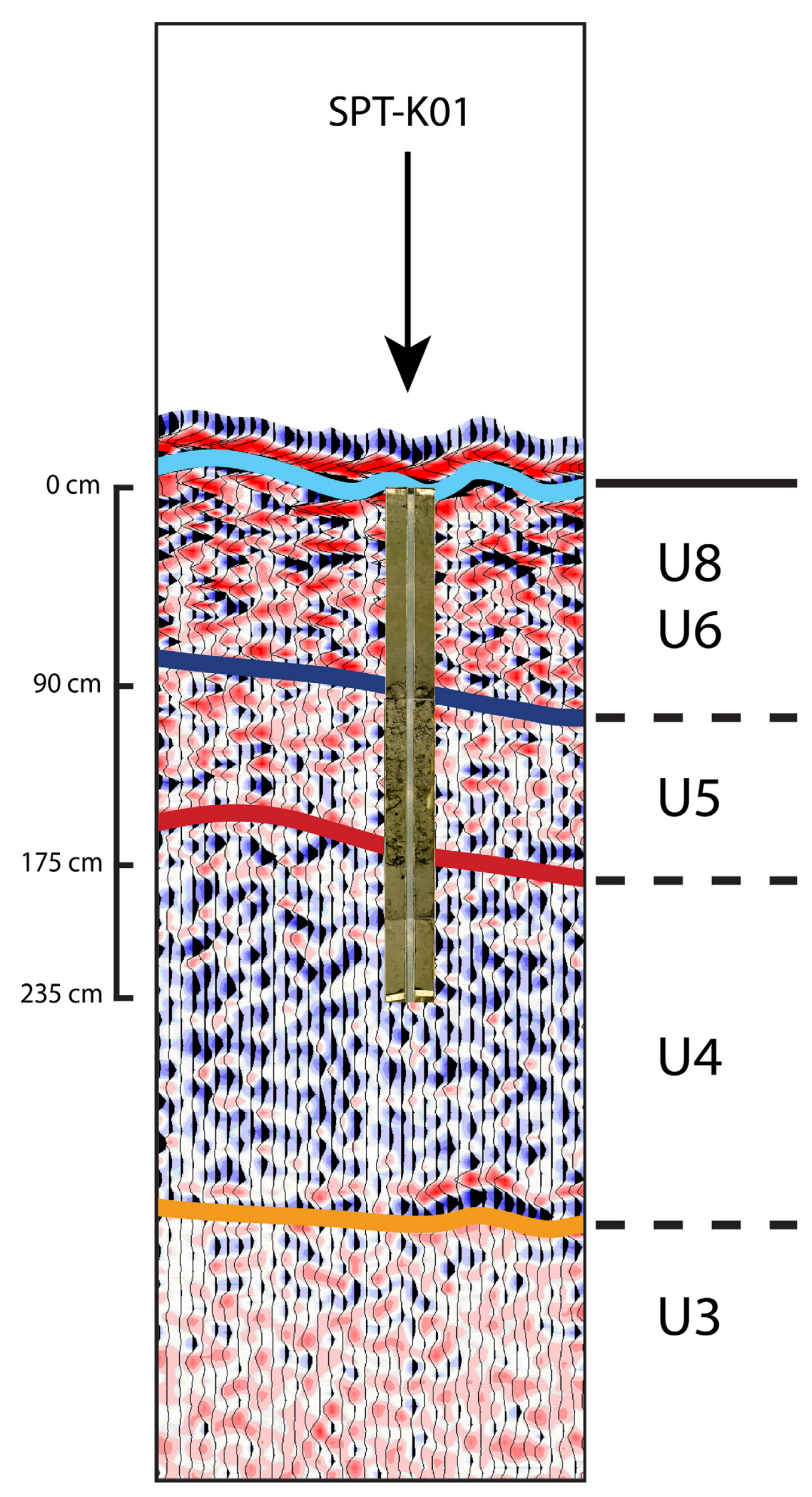

Fig. 9. Core depth to time conversion and core to seismic correlation quality check for SPT-K01 core using SEISEE software.

upper interval of facies A (Fig. 8). The basal interval, which corresponds to the bioclastic sand of facies $\mathrm{C}$, is found in the deepest cores near the edges of the bay (Fig. 8; K04 and K05). The base of this interval was not reached, thus its approximate thickness, while being at least $80 \mathrm{~cm}$, cannot be established from the core description. A thin layer of facies A, approximately 20 to $40 \mathrm{~cm}$ thick, is found on top of facies C. A second interval of debris, corresponding to facies $B$, is found on top of this interval of facies A, and is approximately $1.5 \mathrm{~m}$ thick. Finally, the uppermost unit corresponds to the homogeneous silty facies $\mathrm{A}$, and is between a few tens of centimetres to just over $1 \mathrm{~m}$ thick. Unfortunately, due to a loss of the uppermost sediment record in the Kullenberg cores, the short core and long core sediment samples do not overlap. Thus it is very hard to accurately estimate the total thickness of this upper silt unit in the inner part of the bay. The exception to this sequence is the presence of a thin layer (approximately $30 \mathrm{~cm}$ thick) composed of bioclastic sand in core $\mathrm{K} 02$, corresponding to facies $\mathrm{C}$ just above the coral debris interval composed of facies $B$.

In the shallowest part of the outer domain, the K01 core revealed three sedimentary units. A basal interval of facies A is found, followed by an interval of facies $C$ and a final upper interval of facies A (Fig. 8). The base of the lower silty facies A interval was not reached, thus its accurate thickness of at least $60 \mathrm{~cm}$ remains unknown. The bioclastic sand corresponding to facies $\mathrm{C}$ found on top of the facies A interval is about $90 \mathrm{~cm}$ thick. The thickness of the uppermost interval corresponding to the homogeneous silty facies A cannot be accurately estimated because of uppermost sediment loss during Kullenberg coring. However, its thickness is at least $1.2 \mathrm{~m}$, which is thicker than the upper facies A interval in the cores from the inner domain (Fig. 8; K04, K05, K02 and K07). It is important to emphasize that the facies B interval was found in the inner domain, but is not observed in K01 core nor more distal cores, where only facies A is found on top of facies C. Seaward, in the deeper part of the outer domain (Fig. 3; K03, K21 and K22 cores), only facies A was retrieved in the cores (Table 2; Fig. 8).

\section{Chronology}

The chronology was established using AMS ${ }^{14} \mathrm{C}$ dating of coral fragments and Halimeda plates sampled in most proximal cores except for $\mathrm{K} 03$ (Table 3; Fig. 8) and ${ }^{210} \mathrm{~Pb}$ activity on silty sediment from three short cores (CA02, CA07 and CA01; Fig. 8). Samples were collected only in facies $\mathrm{B}$ and $\mathrm{C}$ for ${ }^{14} \mathrm{C}$ dating and only in facies A for ${ }^{210} \mathrm{~Pb}$ dating. Results are listed from base to top (Table 3; Fig. 8).

Ages obtained close to the upper boundary of the lower facies C interval are: $6215 \mathrm{cal} \mathrm{yr} \mathrm{вP}$ (K04; $40 \mathrm{~cm}$ from interval top); $4150 \mathrm{cal} \mathrm{yr} \mathrm{вр}$ (K04; $80 \mathrm{~cm}$ from interval top) and $3380 \mathrm{cal} \mathrm{yr} \mathrm{вP}$ (K01; $7 \mathrm{~cm}$ from interval top). The age inversion in core $\mathrm{K04}$ is probably related to reworking of material and incorporation of old debris. The age of the basal lower facies C remains unknown, but it was deposited prior to $3380 \mathrm{cal}$ yr вр. 


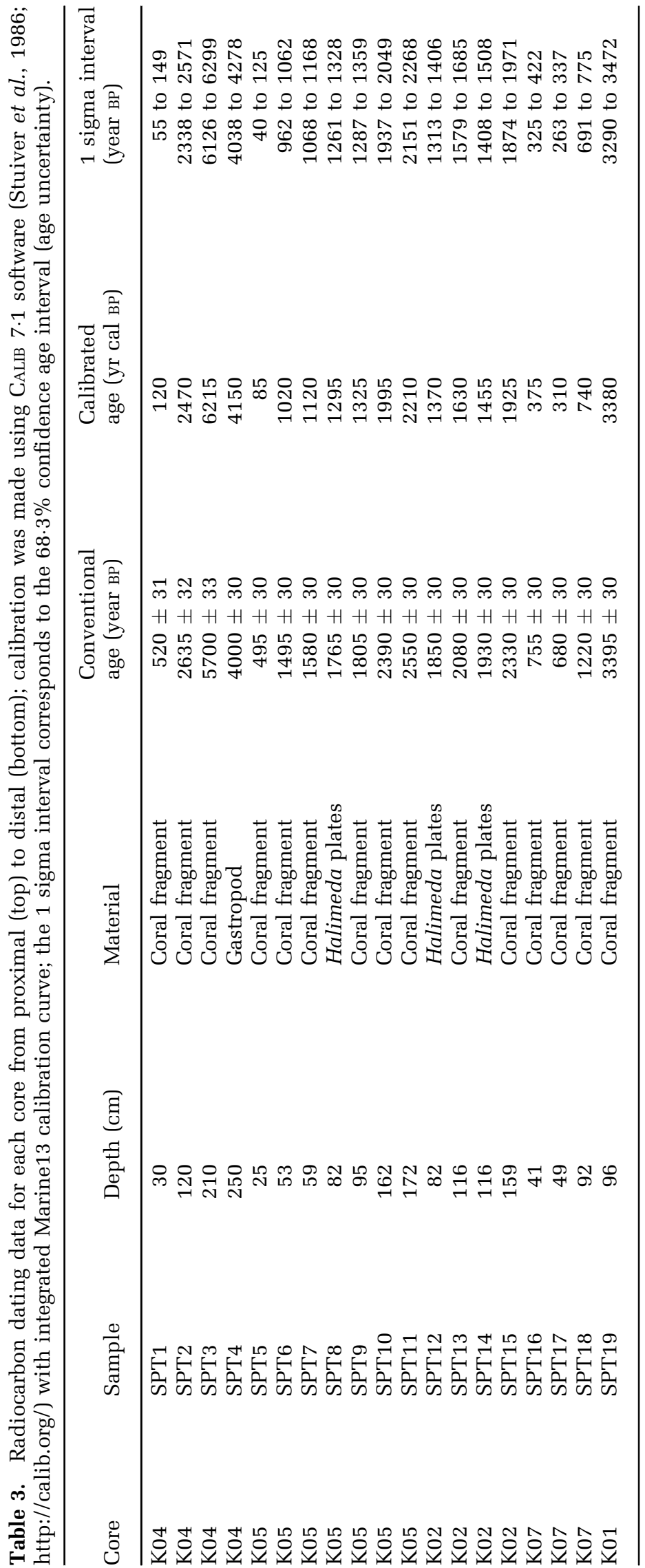


Ages obtained close to the lower boundary of the upper facies B interval are: $2470 \mathrm{cal}$ yr вр (K04; $10 \mathrm{~cm}$ from interval base) and $2210 \mathrm{cal} \mathrm{yr}$ вр (K05; $7 \mathrm{~cm}$ from interval base). Ages obtained close to the upper boundary of the upper facies $\mathrm{B}$ interval are: $120 \mathrm{cal} \mathrm{yr} \mathrm{BP}(\mathrm{K} 04 ; 30 \mathrm{~cm}$ from interval top); $85 \mathrm{cal}$ уг вР (K05; at interval top); $375 \mathrm{cal}$ yr вр (K07; $29 \mathrm{~cm}$ from interval top); $310 \mathrm{cal} \mathrm{yr} \mathrm{вр} \mathrm{(K07;} 38 \mathrm{~cm}$ from interval top) and $1925 \mathrm{cal} \mathrm{yr} \mathrm{вр} \mathrm{(K02;} 36 \mathrm{~cm}$ from interval top). Only one age inversion, close to the age uncertainty ( \pm 30 years), is observed in core K07 (Table 3).

Within core $\mathrm{K} 02$, facies $\mathrm{B}$ is overlain by bioclastic sand corresponding to facies C. Ages for the lower and upper boundaries of this lens are: $1630 \mathrm{cal}$ yr BP $(7 \mathrm{~cm}$ from lens base) and $1370 \mathrm{cal}$ yr вр ( $2 \mathrm{~cm}$ from lens top), respectively. Accumulation rates obtained for the uppermost silt unit are (Table 4): $0.68 \mathrm{~cm} \mathrm{year}^{-1}$ (CA02); $0.84 \mathrm{~cm} \mathrm{year}^{-1}$ (CA07); 0.65 $\mathrm{cm} \mathrm{year}^{-1}$ (CA08) and $0.37 \mathrm{~cm} \mathrm{year}^{-1}$ (CA01).

\section{Core to seismic correlation}

All cores were correlated to seismic profiles after depth to time conversion (Fig. 9), using velocities of: (i) $1600 \mathrm{~m} \mathrm{sec}^{-1}$ for silt material; and (ii) $1800 \mathrm{~m} \mathrm{sec}^{-1}$ for coarse material, according to the relationships between $P$-wave velocities and sediment grain size (Hamilton, 1972). Due to the high resolution of the seismic survey, the uppermost seismic units can be correlated with the three different sedimentary facies A, B and C. Draping units U8, U6 and U4 are correlated with facies A (homogeneous silt deposits) (Figs 4 and 8; K04, K05, K02, K07, K01 and K03). Chaotic seismic unit U7 is correlated with facies B (coral debris unit) (Figs 4 and 8; K04, K05, K02 and K07). Seismic unit U5 is correlated with facies C (bioclastic sand unit) (Figs 4 and 8; K04, K05 and K01). By analogy of seismic architecture and seismic facies, seismic unit U3 is interpreted as composed of coarse debris deposits corresponding to either facies $\mathrm{B}$ or $\mathrm{C}$ (coarse coral fragments and/or bioclastic Halimeda sand), whereas seismic unit U2 is interpreted as composed of facies A (homogeneous silt deposit) (Fig. 4).

The correlation between seismic profiles and sedimentary facies, together with the chronology, allow three debris units to be distinguished. From base to top, they are:

1 At the base, seismic unit U3, which was not retrieved in the cores, but given its similarities with seismic units U5 and U7, is interpreted as being composed of Halimeda sand and/or coarse coral fragments.

2 Seismic unit U5, which extends from the inner to the outer domain of the bay, is composed of a mix of Halimeda sand and coarse coral fragments (Figs 4, 5 and 8; facies C, lower debris unit) and yields ages from $3380 \mathrm{cal}$ уг вр to $6215 \mathrm{cal}$ yr BP (Fig. 8).

3 Seismic unit U7, which is confined to the inner part of the bay, is composed of coarse coral fragments (Figs 4, 5 and 8; facies B, upper debris unit) and yields ages from $85 \mathrm{cal}$ yr BP to 2470 cal yr BP (Fig. 8). Given the important age variations at the top of facies B (from $85 \mathrm{cal} \mathrm{yr}$ вр (K05) to $1370 \mathrm{cal} \mathrm{yr} \mathrm{вр} \mathrm{(K02),} \mathrm{it} \mathrm{is} \mathrm{postulated}$ that erosion of the debris unit occurred in the area of K02. The presence of Halimeda sand lying on the debris unit in K02 reveals a highenergy depositional event that may have followed the erosion surface.

\section{DISCUSSION}

\section{Sequence stratigraphic interpretation of the Pago Pago bay-fill}

The sedimentary fill of Pago Pago Bay consists of eight units, overlying a regional erosional surface (EU0) associated with a strong amplitude reflector at the top of an acoustic basement. Given the origin and history of Tutuila Island as a hotspot volcanic island (McDougall, 1985; Koppers et al., 2008), and since Pago Pago Bay is described as an inundated volcanic caldera (McDougall, 1985), this basement is interpreted as volcanic bedrock. The erosional surface EU0 is interpreted as a sequence boundary formed during successive Quaternary sea level lowstands (Waelbroeck et al., 2002).

The lowest unit identified on top of the volcanic bedrock, unit U1, is characterized by reflectors onlapping onto surface EU0 towards the shore. This specific architecture attests to sediment deposition evolving towards the shore and is typical of transgressive sedimentation (Galloway, 1989; Christie-Blick, 1991). Many coastal lagoons, estuaries and semi-enclosed environments around the world display similar transgressive units at the base of their sedimentfill (Zaitlin et al., 1994; Chaumillon et al., 2010). Therefore, U1 is interpreted as a transgressive unit deposited during a period of sea-level rise. The bounding surface S1 at the top of U1 is a downlap surface (Mitchum, 1977) showing a 

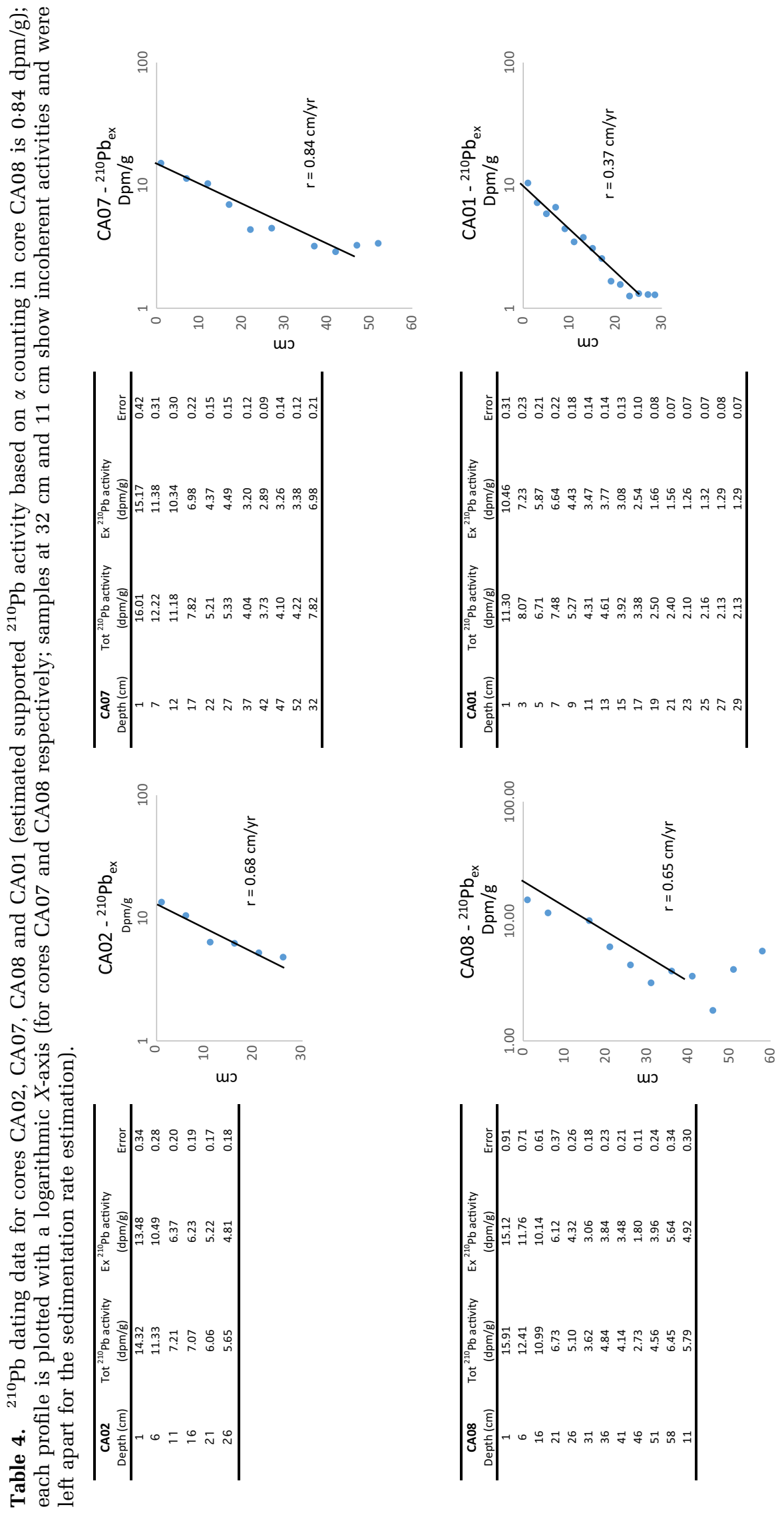
transition from a retrogradational to a progradational pattern. The upper units (U2 to U8) display sub-parallel and sub-horizontal reflectors, with downlapping surfaces (bounding surfaces S3, S5 and S7) typical of an aggradational/ progradational architecture. This architecture is consistent with deposition during a period of sea-level highstand (Catuneanu et al., 2009).

Results of age dating, as well as the absence of any major erosional surface between the volcanic basement and the sea bed, suggest that the whole sedimentary infilling was emplaced during the last eustatic cycle. Following this interpretation, the onlapping unit U2 would correspond to the transgressive systems tract (TST) while the upper prograding/aggrading units (U2 to U8) would correspond to the highstand systems tract (HST). In this context, S1 would correspond to the maximum flooding surface of the bay.

Since local subsidence during the Holocene is negligible (Koppers et al., 2008; McDougall, 2010), the main parameter governing the accommodation space for sedimentation is sea-level variation. Therefore, considering local palaeoeustatism may help in understanding the sediment-fill of the bay. Palaeo-sea level curve reconstruction in the south-west Pacific Ocean (Woodroffe \& Horton, 2005) indicates a mean sea level (m.s.l.) at $-125 \mathrm{~m}$ (from present day m.s.l.) during the last glacial maximum, at around $20000 \mathrm{cal} \mathrm{yr} \mathrm{BP.} \mathrm{At} \mathrm{around} 12000 \mathrm{cal}$ yr $\mathrm{BP}$, the sea level rose to $-65 \mathrm{~m}$ (from present day m.s.l.) which is the approximate depth beneath m.s.l. of the volcanic basement in the outer domain of the bay (Figs 4 and 5). Finally, the present day m.s.l. was reached around $7000 \mathrm{cal}$ yr вр. Given the internal architecture of the Pago Pago bay-fill, which displays two main phases (retrogradation and aggradation/progradation) that were probably emplaced during one sealevel cycle (absence of a strong erosional surface within the sedimentary sequence), it is postulated that the transgressive unit U1 has been emplaced between the early flooding of the bay and the eustatic maximum, between $12000 \mathrm{cal}$ yr вP and $7000 \mathrm{cal}$ yr вр. Then, units U2 to U8 would have been deposited from $7000 \mathrm{cal}$ yr вр to present day. Ages obtained in units U5 and U3 for reworked sediment are congruent with such an interpretation since they do not exceed 6215 cal yr BP. Given the successive highstands and lowstands that occurred in the late Quaternary, the scenario here suggests that the Pago Pago Bay infill that occurs during each highstand (i.e. interglacial period) is completely eroded during the following lowstand (i.e. glacial period).

\section{The 2009 South Pacific Tsunami}

Radiocarbon ages obtained near the upper boundary of unit U7 (up to $85 \mathrm{cal}$ yr $\mathrm{BP}$ ) and ${ }^{210} \mathrm{~Pb}$ data from unit U8 $\left(0 \cdot 65\right.$ to $\left.0 \cdot 84 \mathrm{~cm} \mathrm{year}^{-1}\right)$ in the inner part of Pago Pago Bay indicate that tsunamis from 1917, 1960 and especially 2009 should be recorded in the upper silt unit U8. Based on the sedimentation rate of 0.65 to $0.84 \mathrm{~cm} \mathrm{year}^{-1}$ within unit U8, the 2009 South Pacific Tsunami (SPT) deposit should be found in the first $10 \mathrm{~cm}$ of the short cores. Unfortunately, no visual trace of these tsunamis was observed in the cores (Fig. 10), indicating that the 2009 SPT deposit within the sampled cores is not associated with any grain-size change and marked sedimentation change. Nevertheless, Xray fluorescence (XRF) data measured on most of the short cores show a peak of the Ti/Ca ratio at approximately 7 to $9 \mathrm{~cm}$ depth (Fig. 10). While no chemical analysis of inland tsunami deposits has previously been carried out on Tutuila Island, data from Satitoa (Upolu Island, Samoa) show that the 2009 SPT inland deposit is rich in calcium (Ca), reflecting the source material from the coral reef, while the underlying soil is enriched in titanium (Ti), due to the volcanic nature of the parent rock on the island (ChaguéGoff et al., 2011, 2017). High counts of Ca often indicate the occurrence of biogenic markers, such as shell, shell hash and carbonate, and are therefore used as indicators of a marine source (Chagué-Goff et al., 2017). Since Tutuila Island is also volcanic, a similar approach can be used to interpret the peak in Ti/Ca in the marine sediment. Therefore, the observed peak in $\mathrm{Ti} / \mathrm{Ca}$ most likely represents a terrestrial sediment input that could be associated with the backwash deposit of the 2009 SPT. No other peak, potentially associated with the historical 1917 and 1960 tsunamis, was observed clearly deeper in the cores. This could be explained by a wave height and impact, hence less terrestrial sediment input. Similar findings have also been reported by (Sakuna et al., 2012; SakunaSchwartz et al., 2015) who analyzed offshore sediment cores, searching for evidence of backwash following the 2004 Indian Ocean tsunami in Thailand. It is also worth noting that chemical signatures can in some instances reveal the occurrence of event deposits that were otherwise 


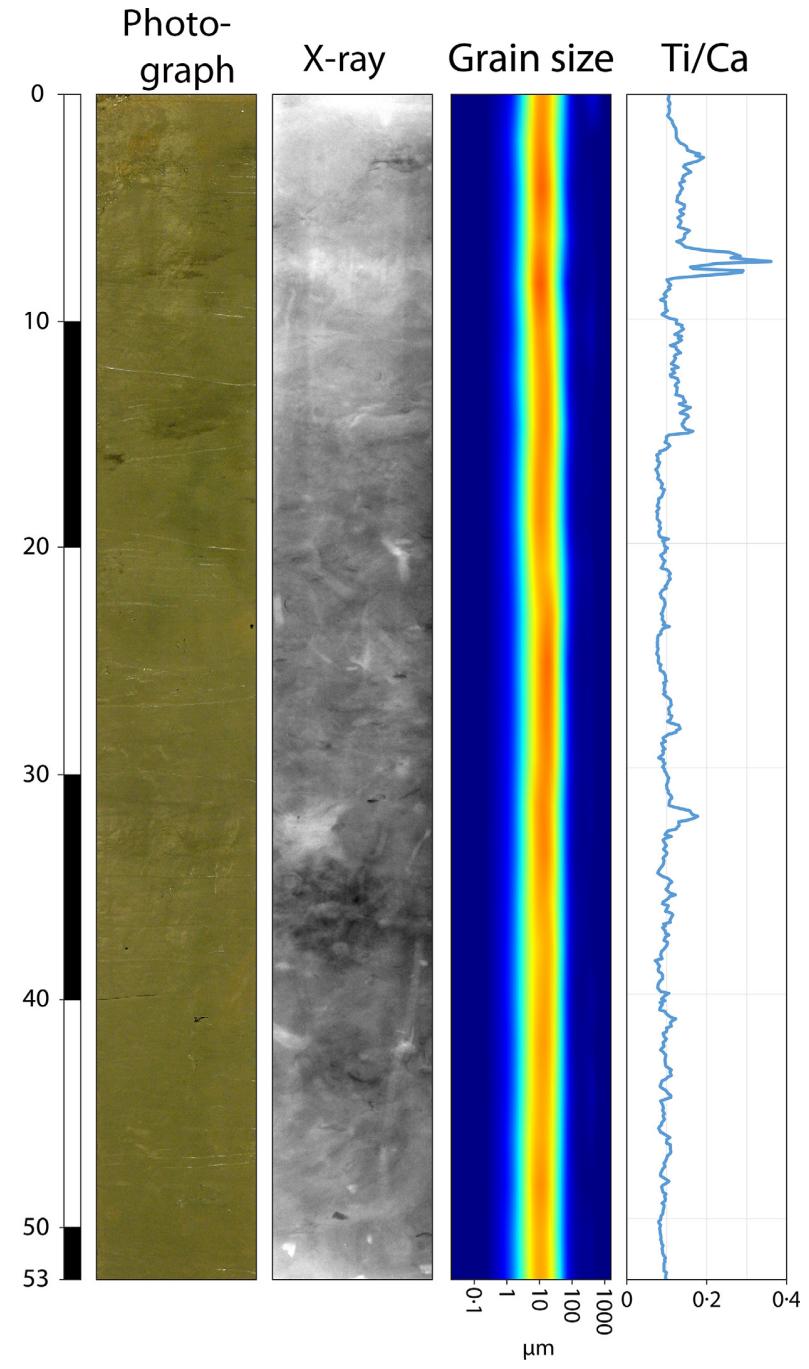

Fig. 10. Multi-proxy approach of 2009 SPT deposits identification on core CA07; from left to right respectively, photograph, X-ray and grain size do not show any evidence of tsunami backwash deposits (no variations), while a peak of terrestrial input can be spotted between $7 \mathrm{~cm}$ and $9 \mathrm{~cm}$ on X-ray fluorescence (XRF) data.

not visible to the naked eye (Chagué-Goff et al., 2016). It is the case in this study where, even if a multi-proxy approach was used to identify the 2009 SPT deposits, only through this chemical signature was it detectable. It might appear intriguing that the sedimentary record of the 2009 SPT is hardly discernible whereas much land and infrastructure damage was reported onland (Fritz et al., 2011). Major soil erosion was observed and anthropogenic material was washed out to the sea during backwash (Jaffe et al., 2010). It is therefore likely, given the mounds and deep sea floor morphology, that most of the material washed out to sea was deposited and captured in mini-basins close to shore, in shallow areas $(<15 \mathrm{~m})$, where this study was not able to make a seismic survey and collect cores. In relatively deep areas, it is assumed that the material deposited during and after the 2009 SPT consists of mud derived from soil erosion. (Feldens et al., 2012) also reported that offshore deposits related to the 2004 tsunami in Thailand could only be found at shallow depths (9 to $15 \mathrm{~m}$ ).

\section{Origin of coral debris}

The upper aggradational/progradational sequence (HST) is characterized by a changeover in the sedimentation between homogeneous low-energy silt deposits (U2, U4, U6 and U8) and very coarse coral debris and Halimeda deposits (U3, U5 and U7). These changeovers in the upper metres of the Pago Pago bay-fill indicate alternation of high energy (facies B and C in U3, U5 and U7) and low energy (facies A in U2, U4, U6 and U8) sedimentation phases. The coral fragments found in facies B (U3, U5 and U7) all show very fresh cuts (Fig. 7) and have not been colonized by aquatic organisms after death. Besides, no intact or in living position corals are found. This suggests transportation after a high-energy event and rapid sedimentation under overlying mud. The freshness of the cuts also implies a local source, inferring that corals were most likely broken while still alive and transported over a relatively short distance. Thus, these debris indicate a very highly dynamic event, such as extreme wave events.

Two alternative processes, tropical storms and tsunamis, may have produced such highly dynamic events and must be considered. Given that the coral fragments are composed of shallow water species, both storm waves and tsunami waves are able to break and transport such fragments. Deep marine species were not identified in the debris deposits, which would have indicated reworking by long wavelength waves, such as tsunami waves, rather than storm waves. Nevertheless, the depth of marine species found in such deposits is not necessarily a criterion to differentiate storm and tsunami deposits, because onshore studies of the 2009 SPT deposits on Upolu Island (Chagué-Goff et al., 2011) showed that the sediment source was from the nearshore and there was no evidence of fauna deeper than $10 \mathrm{~m}$.

The only argument that may favour the tsunami origin for those coarse coral and Halimeda 
debris units is related to the morphology of the bay. Pago Pago Bay is a deep and sheltered bay whose morphology is ideal for dissipating storm waves. However, the funnel shape of the bay greatly amplified the tsunami waves from around $1 \mathrm{~m}$ at the entrance to 7 to $8 \mathrm{~m}$ in the inner bay during the 2009 SPT (Fritz et al., 2011). Finally, due to the geodynamic context and the sheltered morphology of Pago Pago Bay, the most likely high energy events responsible for the coarse coral and Halimeda debris units are tsunamis, which are able to break such coarse coral fragments from the mouth and sides of the bay and carry them towards the end of the bay into $60 \mathrm{~m}$ water depth.

The absence of coral debris in the upper sediment-fill of Pago Pago Bay, where 2009 SPT related deposits are expected to occur, seriously challenges the hypothesis of a tsunami origin for the underlying coral debris. Meanwhile, it is assumed that this absence of coral debris is a consequence of the arrival of the settlers in Tutuila and the expansion of the harbour, which began around 150 years ago. The age of the transition between the coral debris of unit U7 and the homogeneous silts of unit U8 (Fig. 8), at the end of the 19th Century, coincides approximately with the intense anthropization of Pago Pago Harbor. A resurvey by (Cornish \& DiDonato, 2004) of a reef flat earlier described by (Mayor, 1920) allowed a comparative study between 1920 and 2004 and showed that this anthropization resulted in the decline of the coral colonies of Pago Pago Bay. Following this hypothesis, the decline of the reef colonies in the bay induced a lack of available coral to be broken and carried away during the most recent tsunamis, including that in 2009 , but also during the 1917 and 1960 tsunamis, as observed in the cores. Beyond the decline of corals, anthropization has resulted in a progressive siltation of Pago Pago Bay, as shown by the thick U8 silt unit (facies A). A similar siltation of coastal environments, in response to deforestation and anthropization has been observed worldwide (Poirier et al., 2011).

Silty sequences are also observed in deeper U6 and U4 units, with a thousand-year period for U6. Given their age, prior to $2470 \mathrm{cal}$ yr вP (Fig. 8), these deposits cannot be correlated to anthropization. Thus, two alternative hypotheses can be proposed to explain the presence of such fine deposits (facies A) interstratified between coarse coral fragments (facies B and C): either no tsunami occurred during these silty periods, or no local coral source was available for tsunami waves to mobilize.

The first hypothesis, where no tsunamis occurred during a period of a millennium or so, emphasizes an alternation between time spans with a high tsunami recurrence and some with no tsunami. However, most tsunamis, and especially those impacting the Samoan archipelago, are triggered by underwater earthquakes (Pararas-Carayannis \& Dong, 1980). The two greatest historical tsunamis to hit Pago Pago Bay (Dominey-Howes \& Thaman, 2009; Beavan et al., 2010; Lay et al., 2010; Goff \& Dominey-Howes, 2011; Okal et al., 2011) were triggered by earthquakes on the Tonga Trench. This alternation between periods of intense tsunami recurrence and periods without tsunamis could be related to alternation between active tectonic phases of the Tonga Trench subduction, during constraint discharge, and dormant phases, during constraint accumulation. Such long-term tectonic phases at plate boundaries have been pointed out elsewhere (Imamura, 1937; Marco et al., 1996; Kelsey et al., 2005; Dolan et al., 2007) but never for the Tonga Trench.

The second hypothesis, where no local coral source is available for tsunami waves to mobilize, implies a variation of the availability of the local coral source over the late Holocene or a change in coral population (with the development of less fragile species such as massive Poritidae or Favidae). Such variations on the development of reef colonies could be related to palaeo-climatic or palaeo-environmental changes. However, neither a sea level variation (Lambeck et al., 2014) nor drastic sea surface temperature variations (Rosenthal et al., 2013) capable of killing coral colonies were recorded during the late Holocene in the south-west Pacific Ocean. However, corals are also highly sensitive to salinity and turbidity variation (Veron \& Stafford-Smith, 2000). Thus, the absence of corals could be interpreted as periods of high precipitation resulting in high erosion rates on the island and sediment supply to the coast, and lower salinity. Further palaeo-climatic studies would be needed to warrant this hypothesis.

Another major question related to these findings is how many tsunami events may have produced such thick coarse coral and Halimeda debris units (facies B and C correlated to seismic units U5 and U7)? Unfortunately, no major discontinuity or erosion surface is visible in the cores within facies $\mathrm{B}$ and $\mathrm{C}$, and no specific event stands out in the dating results. Thus it is 
impossible to say how many tsunamis occurred during these time intervals. Either way, it would have been hardly possible given the probability of erosion between different waves for the same event, but also of eroding a preceding tsunami during each event.

\section{CONCLUSION}

The goal of this study was to gain a better understanding of the architecture and history of the sedimentary infilling in Pago Pago Bay, in order to set the context for future more detailed studies on the impacts of the 2009 South Pacific Tsunami (SPT) and older tsunami events. Using bathymetry, the atypical geomorphology of the sea floor was first documented. Two domains bounded by the $40 \mathrm{~m}$ isobath were identified. The inner part of the bay, shallower than $40 \mathrm{~m}$ depth, is characterized by a succession of mounds and troughs. On the other hand, the outer part of the bay, deeper than $40 \mathrm{~m}$, is characterized by a smooth and gentle slope with no specific geomorphological features.

Based on seismic profiles and sediment cores, eight sedimentary units were then identified overlying an eroded volcanic bedrock. These units are interpreted as corresponding to the sedimentary infilling of Pago Pago Bay during the sea-level rise that followed the last glacial maximum and reached the bay 12000 years ago. The base of the sediment fill is a transgressive unit, overlain by aggradational highstand tract units deposited during the last 6000 years of high sea level. These units attest to a changeover in the nature of the sedimentation between homogeneous silt units and coarse coral and Halimeda debris units pinching out seaward. The size and shape of these coral fragments, combined with the highly sheltering morphology of Pago Pago Bay, reveal the tsunamiinduced nature of these deposits. The reason for the alternation between homogeneous silt units and tsunami-induced coral debris units is not yet known. Two hypotheses are proposed. The first is a variation of the tectonic activity of the Tonga Trench subduction during the Holocene, resulting in phases of active tectonic activity followed by phases of tectonic quiescence connected to variation of the tsunami recurrence. As such, tectonic cycles have never been described in the south-west Pacific during the Holocene, only a new palaeo-seismological study could validate or disprove this hypothesis.
The second one is a variation of the palaeo-climatic conditions, especially precipitation, controlling the abundance of local reef colonies, and thus the availability of the coral source. A local palaeo-climatic study, using for example the geochemistry of Halimeda plates, could help to strengthen this hypothesis.

Evidence of backwash deposits caused by the 2009 SPT was found as a result of X-ray fluorescence (XRF) data. No other classical determination methods used nowadays to detect tsunami deposits have proved effective. A second study will focus on these discrete 2009 SPT backwash deposits using mainly geochemical analyses. Finally, the sedimentary record of Pago Pago Bay now constitutes a reference section for studies conducted in other bays around Tutuila Island and the Samoan archipelago.

\section{ACKNOWLEDGEMENTS}

We would like to thank first the CNRS-INSU "Risques et catastrophes telluriques" program and the Conseil Regional de la Région Poitou Charentes who made all of this possible by funding the whole project. A special thanks is addressed to the Commission Nationale de la Flotte Côtière, to the captain Jean-François Barazer and crew of the $R / V$ Alis, to the divers Stéphane Bujan and John Butscher, along with Bruce Jaffe for his help coordinating the field survey. Appreciation also goes to John-Patrick Walsh and Reide Corbett for ${ }^{210} \mathrm{~Pb}$ dating, and Pierre Sabatier for helping in its interpretation. Additional appreciation to the members of the EPOC lab core analysis platform Isabelle Billy, Pascal Lebleu, Marie-Claire Perello and Olivier Ther as well as GIS expert Vincent Hanquiez and interns Johanna Juppin and Laurine Monier. Finally, we would like to acknowledge the two anonymous reviewers along with Associate Editor Pedro Costa for their thoughtful and constructive comments.

\section{REFERENCES}

Abrantes, F., Alt-Epping, U., Lebreiro, S., Voelker, A. and Schneider, R. (2008) Sedimentological record of tsunamis on shallow-shelf areas: The case of the 1969 AD and 1755 $\mathrm{AD}$ tsunamis on the Portuguese Shelf off Lisbon. Mar. Geol., 249, 283-293.

Allard, J., Chaumillon, E., Bertin, X., Poirier, C. and Ganthy, F. (2010) Sedimentary record of environmental changes and human interferences in a macrotidal bay for the last millenaries: the Marennes-Oléron Bay (SW 
France). Bulletin de la Société Géologique de France, 181, 151-169.

Apotsos, A., Gelfenbaum, G., Jaffe, B., Watt, S., Peck, B., Buckley, M. and Stevens, A. (2011) Tsunami inundation and sediment transport in a sediment-limited embayment on American Samoa. Earth Sci. Rev., 107, 1-11.

Atwater, B.F. (1987) Evidence for great Holocene earthquakes along the outer coast of Washington state. Science, 236, 942-944.

Beavan, J., Wang, X., Holden, C., Wilson, K., Power, W., Prasetya, G., Bevis, M. and Kautoke, R. (2010) Nearsimultaneous great earthquakes at Tongan megathrust and outer rise in September 2009. Nature, 466, 959-963.

Beta Analytics (2012) Introduction to radiocarbon determinations by the accelerator mass spectrometry method.

Billeaud, I., Chaumillon, E. and Weber, O. (2005) Evidence of a major environmental change recorded in a macrotidal bay (Marennes-Oléron Bay, France) by correlation between VHR seismic profiles and cores. Geo-Mar. Lett., 25, 1-10.

Catuneanu, O., Abreu, V., Bhattacharya, J.P., Blum, M.D., Dalrymple, R.W., Eriksson, P.G., Fielding, C.R., Fisher, W.L., Galloway, W.E., Gibling, M.R., Giles, K.A., Holbrook, J.M., Jordan, R., Kendall, C.G.S.C., Macurda, B., Martinsen, O.J., Miall, A.D., Neal, J.E., Nummedal, D., Pomar, L., Posamentier, H.W., Pratt, B.R., Sarg, J.F., Shanley, K.W., Steel, R.J., Strasser, A., Tucker, M.E. and Winker, C. (2009) Towards the standardization of sequence stratigraphy. Earth Sci. Rev., 92, 1-33.

Chagué-Goff, C., Schneider, J.-L., Goff, J.R., DomineyHowes, D. and Strotz, L. (2011) Expanding the proxy toolkit to help identify past events - Lessons from the 2004 Indian Ocean Tsunami and the 2009 South Pacific Tsunami. Earth Sci. Rev., 107, 107-122.

Chagué-Goff, C., Chan, J.C.H., Goff, J. and Gadd, P. (2016) Late Holocene record of environmental changes, cyclones and tsunamis in a coastal lake, Mangaia, Cook Islands. Island Arc., 25, 333-349.

Chagué-Goff, C., Szczuciński, W. and Shinozaki, T. (2017) Applications of geochemistry in tsunami research: A review. Earth Sci. Rev., 165, 203-244.

Chaumillon, E., Bertin, X., Falchetto, H., Allard, J., Weber, N., Walker, P., Pouvreau, N. and Woppelmann, G. (2008) Multi time-scale evolution of a wide estuary linear sandbank, the Longe de Boyard, on the French Atlantic coast. Mar. Geol., 251, 209-223.

Chaumillon, E., Tessier, B. and Reynaud, J.-Y. (2010) Stratigraphic records and variability of incised valleys and estuaries along French coasts. Bulletin de la Société Géologique de France, 181, 75-85.

Christie-Blick, N. (1991) Onlap, offlap, and the origin of unconformity-bounded depositional sequences. Mar. Geol., 97, 35-56.

Clark, J.T., Quintus, S., Weisler, M.I., Pierre, E.S., Nothdurft, L., Feng, Y. and Hua, Q. (2016) Marine Reservoir Correction for American Samoa Using U-series and AMS Dated Corals. Radiocarbon, 58, 851-868.

Cornish, A.S. and DiDonato, E.M. (2004) Resurvey of a reef flat in American Samoa after 85 years reveals devastation to a soft coral (Alcyonacea) community. Mar. Pollut. Bull., 48, 768-777.

Dawson, A.G. and Stewart, I. (2007) Tsunami deposits in the geological record. Sed. Geol., 200, 166-183.

Dolan, J.F., Bowman, D.D. and Sammis, C.G. (2007) Longrange and long-term fault interactions in Southern California. Geology, 35, 855-858.
Dominey-Howes, D. and Thaman, R. (2009) UNESCO-IOC International Tsunami Survey Team Samoa (ITST Samoa) Interim Report of Field Survey, 14th-21st October 2009. Australian Tsunami Research Centre.

Donato, S.V., Reinhardt, E.G., Boyce, J.I., Pilarczyk, J.E. and Jupp, B.P. (2009) Particle-size distribution of inferred tsunami deposits in Sur Lagoon, Sultanate of Oman. Mar. Geol., 257, 54-64.

Feldens, P., Schwarzer, K., Sakuna, D., Szczuciński, W. and Sompongchaiyakul, P. (2012) Sediment distribution on the inner continental shelf off Khao Lak (Thailand) after the 2004 Indian Ocean tsunami. Earth Planet Sp, 64, 7.

Fritz, H.M., Borrero, J.C., Synolakis, C.E., Okal, E.A., Weiss, R., Titov, V.V., Jaffe, B.E., Foteinis, S., Lynett, P.J., Chan, I.-C. and Liu, P.L.-F. (2011) Insights on the 2009 South Pacific tsunami in Samoa and Tonga from field surveys and numerical simulations. Earth Sci. Rev., 107, 66-75.

Fujiwara, O. and Kamataki, T. (2007) Identification of tsunami deposits considering the tsunami waveform: An example of subaqueous tsunami deposits in Holocene shallow bay on southern Boso Peninsula, Central Japan. Sed. Geol., 200, 295-313.

Galloway, W.E. (1989) Genetic stratigraphic sequences in basin analysis I: architecture and genesis of flooding-surface bounded depositional units. AAPG Bull., 73, 125-142.

Gelfenbaum, G., Apotsos, A., Stevens, A.W. and Jaffe, B. (2011) Effects of fringing reefs on tsunami inundation: American Samoa. Earth Sci. Rev., 107, 12-22.

Goff, J. and Dominey-Howes, D. (2011) The 2009 South Pacific Tsunami. Earth Sci. Rev., 107, v-vii.

Green, A., Authority, G.B.R.M.P. and Pago, P. (2002) Status of coral reefs on the main volcanic islands of American Samoa. Available at: http://www.nodc.noaa.gov/cgi-bin/ OAS/prd/accession/download/0001976

Hamilton, E. (1972) Compressional-wave attenuation in marine sediments. Geophysics, 37, 620-646.

Hitchcock, C.H. (1911) Hawaii and its Volcanoes. Hawaiian Gazette Company, Honolulu, 314 pp.

Imamura, A. (1937) Theoretical and Applied Seismology. Maruzen Company, Tokyo, 358 pp.

Ishimura, D. and Miyauchi, T. (2015) Historical and paleotsunami deposits, during the last 4000 years and their correlations with historical tsunami events in Koyadori on the Sanriku Coast, northeastern Japan. Prog. Earth Planet. Sci., 2, 16. https://doi.org/10.1186/s40645-015-0047-4

Jaffe, B.E. and Gelfenbaum, G. (2002) Using tsunami deposits to improve assessment of tsunami risk. Solutions to Coastal Disasters' 02, 836-847.

Jaffe, B.E. and Gelfenbuam, G. (2007) A simple model for calculating tsunami flow speed from tsunami deposits. Sed. Geol., 200, 347-361.

Jaffe, B.E., Gelfenbaum, G., Buckley, M.L., Watt, S., Apotsos, A., Stevens, A.W. and Richmond, B.M. (2010) The limit of inundation of the September 29, 2009, tsunami on Tutuila, American Samoa. U. S. Geological Survey Open-File Report 2010-1018, 27 pp.

Kelsey, H.M., Nelson, A.R., Hemphill-Haley, E. and Witter, R.C. (2005) Tsunami history of an Oregon coastal lake reveals a $4600 \mathrm{yr}$ record of great earthquakes on the Cascadia subduction zone. GSA Bull., 117, 1009-1032.

Koppers, A.A.P., Russell, J.A., Jackson, M.G., Konter, J., Staudigel, H. and Hart, S.R. (2008) Samoa reinstated as a primary hotspot trail. Geology, 36, 435.

Kullenberg, B. (1947) The Piston Core Sampler. Svenska Hydr.-Biol. Kommissionens, Göteborg, 46 pp. 
Lambeck, K., Rouby, H., Purcell, A., Sun, Y. and Sambridge, M. (2014) Sea level and global ice volumes from the Last Glacial Maximum to the Holocene. Proc. Natl Acad. Sci., 111, 15296-15303.

Lay, T., Ammon, C.J., Kanamori, H., Rivera, L., Koper, K.D. and Hutko, A.R. (2010) The 2009 Samoa-Tonga great earthquake triggered doublet. Nature, 466, 964-968.

Marco, S., Stein, M., Agnon, A. and Ron, H. (1996) Longterm earthquake clustering: A 50 000-year paleoseismic record in the Dead Sea Graben. J. Geophys. Res. Solid Earth, 101, 6179-6191.

Mayor, A.G. (1920) The reefs of Tutuila, Samoa, in their relation to Coral Reef theories. Proc. Am. Philos. Soc., 59, 224-236.

McDougall, I. (1985) Age and evolution of the volcanoes of Tutuila, American Samoa.

McDougall, I. (2010) Age of volcanism and its migration in the Samoa Islands. Geol. Mag., 147, 705-717.

Mitchum, R.J. (1977) Seismic stratigraphy and global changes of sea level: Part 11. Glossary of terms used in seismic stratigraphy: Section 2. Application of seismic reflection configuration to stratigraphic interpretation. American Association of Petroleum Geologists, Memoir 26, 165, 205-212.

Monecke, K., Finger, W., Klarer, D., Kongko, W., McAdoo, B.G., Moore, A.L. and Sudrajat, S.U. (2008) A 1,000-year sediment record of tsunami recurrence in northern Sumatra. Nature, 455, 1232-1234.

Mosher, D.C. and Simpkin, P.G. (1999) Environmental Marine Geoscience 1. Status and trends of marine highresolution seismic reflection profiling: data acquisition. Geosci. Can., 26, 174-188.

Nanayama, F. (2008) Sedimentary characteristics and depositional processes of onshore tsunami deposits: An example of sedimentation associated with the 12 July 1993 Hokkaido-Nansei-Oki Earthquake Tsunami. In: Tsunamiites (Eds T. Shiki, Y. Tsuji, T. Yamazaki and K. Minoura), pp. 63-80. Elsevier, Amsterdam.

Nanayama, F., Satake, K., Furukawa, R., Shimokawa, K., Atwater, B.F., Shigeno, K. and Yamaki, S. (2003) Unusually large earthquakes inferred from tsunami deposits along the Kuril trench. Nature, 424, 660.

NGDC (2018) NGDC/WDS Global Historical Tsunami Database| NCEI. https://www.ngdc.noaa.gov/hazard/tsu_db.shtml

Nittrouer, C.A., Sternberg, R.W., Carpenter, R. and Bennett, J.T. (1979) The use of Pb-210 geochronology as a sedimentological tool: Application to the Washington continental shelf. Mar. Geol., 31, 297-316.

NOAA Service National Weather (2018) National Tsunami Warning Center - Samoa Islands Region Tsunami of 29 September 2009. http://wcatwc.arh.noaa.gov/previous.eve nts/?p = 09-29-09-Samoa

Okal, E.A., Borrero, J.C. and Chagué-Goff, C. (2011) Tsunamigenic predecessors to the 2009 Samoa earthquake. Earth Sci. Rev., 107, 128-140.

Pararas-Carayannis, G. and Dong, B. (1980) Catalog of Tsunamis in the Samoan Islands. Intl. Tsunami Infor Center, Honolulu, 75 pp.

Petchey, F., Anderson, A., Zondervan, A., Ulm, S. and Hogg, A. (2008) New marine $\Delta \mathrm{R}$ values for the South Pacific subtropical gyre region. Radiocarbon, 50, 373-397.

Pinegina, T.K. and Bourgeois, J. (2001) Historical and paleotsunami deposits on Kamchatka, Russia: long-term chronologies and long-distance correlations. Nat. Hazard. Earth Syst. Sci., 1, 177-185.
Poirier, C., Chaumillon, E. and Arnaud, F. (2011) Siltation of river-influenced coastal environments: Respective impact of late Holocene land use and high-frequency climate changes. Mar. Geol., 290, 51-62.

Reimer, P.J., Bard, E., Bayliss, A., Beck, J.W., Blackwell, P.G., Ramsey, C.B., Buck, C.E., Cheng, H., Edwards, R.L., Friedrich, M., Grootes, P.M., Guilderson, T.P., Haflidason, H., Hajdas, I., Hatte, C., Heaton, T.J., Hoffmann, D.L., Hogg, A.G., Hughen, K.A., Kaiser, K.F., Kromer, B., Manning, S.W., Niu, M., Reimer, R.W., Richards, D.A., Scott, E.M., Southon, J.R., Staff, R.A., Turney, C.S.M. and van der Plicht, J. (2016) IntCal13 and Marine13 radiocarbon age calibration curves 0-50,000 years cal BP. Radiocarbon, 55, 1869-1887.

Rosenthal, Y., Linsley, B.K. and Oppo, D.W. (2013) Pacific ocean heat content during the past 10000 Years. Science, 342, 617-621.

Rubin, C.M., Horton, B.P., Sieh, K., Pilarczyk, J.E., Daly, P., Ismail, N. and Parnell, A.C. (2017) Highly variable recurrence of tsunamis in the 7400 years before the 2004 Indian Ocean tsunami. Nat. Commun., 8, 16019.

Sakuna, D., Szczuciński, W., Feldens, P., Schwarzer, K. and Khokiattiwong, S. (2012) Sedimentary deposits left by the 2004 Indian Ocean tsunami on the inner continental shelf offshore of Khao Lak, Andaman Sea (Thailand). Earth, Planets and Space, 64, 931-943.

Sakuna-Schwartz, D., Feldens, P., Schwarzer, K., Khokiattiwong, S. and Stattegger, K. (2015) Internal structure of event layers preserved on the Andaman Sea continental shelf, Thailand: tsunami vs. storm and flashflood deposits. Nat.Haz. Earth Syst. Sci., 15, 1181-1199.

Simpkin, P.G. and Davis, A. (1993) For seismic profiling in very shallow water, a novel receiver. Sea Technol., 24, 5.

Smedile, A., De Martini, P.M., Pantosti, D., Bellucci, L., Del Carlo, P., Gasperini, L., Pirrotta, C., Polonia, A. and Boschi, E. (2011) Possible tsunami signatures from an integrated study in the Augusta Bay offshore (Eastern Sicily-Italy). Mar. Geol., 281, 1-13.

Smedile, A., De Martini, P.M. and Pantosti, D. (2012) Combining inland and offshore paleotsunamis evidence: the Augusta Bay (eastern Sicily, Italy) case study. Nat. Haz. Earth Syst. Sci., 12, 2557-2567.

Stuiver, M., Pearson, G.W. and Braziunas, T. (1986) Radiocarbon age calibration of marine samples back to 9000 cal yr вр. Radiocarbon, 28, 980-1021.

Sugawara, D., Minoura, K., Nemoto, N., Tsukawaki, S., Goto, K. and Imamura, F. (2009) Foraminiferal evidence of submarine sediment transport and deposition by backwash during the 2004 Indian Ocean tsunami. Island Arc., 18, 513-525.

Van Den Bergh, G.D., Boer, W., De Haas, H., Van Weering, T.C. and Van Wijhe, R. (2003) Shallow marine tsunami deposits in Teluk Banten (NW Java, Indonesia), generated by the 1883 Krakatau eruption. Mar. Geol., 197, 13-34.

Veron, J.E.N. and Stafford-Smith, M. (2000) Corals of the World. Volumes 1-3. Australian Institute of Marine Science, Townsville, $1382 \mathrm{pp}$.

Waelbroeck, C., Labeyrie, L., Michel, E., Duplessy, J.C., McManus, J.F., Lambeck, K., Balbon, E. and Labracherie, M. (2002) Sea-level and deep water temperature changes derived from benthic foraminifera isotopic records. Quatern. Sci. Rev., 21, 295-305.

Weiss, R. and Bahlburg, H. (2006) A note on the preservation of offshore tsunami deposits. J. Sediment. Res., 76, 1267-1273. 
Williams, S.P., Goff, J.R., Sale, F., Ahkau, J., Prasetya, G., Davies, T.R., Cheung, K.F. and Wilson, T. (2011) Sands of Time: Evidence for palaeotsunamis and/or palaeostorms in Samoa, and what this means for tsunami risk reduction. In: Proceedings of the Samoa National Environment Forum, 2010, 15-25.

Woodroffe, S.A. and Horton, B.P. (2005) Holocene sea-level changes in the Indo-Pacific. J. Asian Earth Sci., 25, 29-43.
Zaitlin, B.A., Dalrymple, R.W. and Boyd, R. (1994) The stratigraphic organization of incised-valley systems associated with relative sea-level change. In: Incised-Valley Systems: Origin and Sedimentary Sequences (Eds R.W. Dalyrmple, R. Boyd and B.A. Zaitlin), SEPM Spec Publ., 51, 45-60.

Manuscript received 1 June 2018; revision accepted 20 December 2018 